\title{
ined(0)
}

https://archined.ined.fr

\section{The Great Convergence? Gender and Unpaid Work in Europe and the United States}

\author{
Ariane Pailhé, Anne Solaz et Maria Stanfors
}

\section{Version}

Libre accès

\section{POUR CITER CETTE VERSION / TO CITE THIS VERSION}

Ariane Pailhé, Anne Solaz et Maria Stanfors, 2020, "The Great Convergence? Gender and Unpaid Work in Europe and the United States". Lund Papers in Economic Demography, n²020-1, Lund :

Disponible sur / Availabe at:

http://hdl.handle.net/20.500.12204/AXFVQlD_UClQnEe2WFOs 


\section{The Great Convergence? Gender and Unpaid Workin Europe and the United States}

ARIANE PAILHÉ, ANNE SOLAZ, MARIA STANFORS

LUND PAPERS IN ECONOMIC DEMOGRAPHY 2020:1

Centre for Economic Demography

Lund University School of Economics and Management P.O. Box 7083

SE-220 07 Lund, Sweden www.ed.lu/publications/Lund-Papers-in-Economic-Demography/ 


\section{CENTRE FOR ECONOMIC DEMOGRAPHY}

The Centre for Economic Demography (CED), established in 2006 as a Linnaeus Centre of Excellence, is a multidisciplinary research centre at Lund University with members from the School of Economics and Management, the Faculty of Medicine and the Faculty of Social Sciences. The mission of CED is to promote research and training in population studies. Researchers at the Centre study demographic issues from different perspectives and in a variety of contexts across time and space. More information at www.ed.lu.

Copyright is held by the author(s). Lund Papers in Economic Demography are circulated for discussion and have not been peer-reviewed or reviewed by the Centre for Economic Demography. The views expressed are those of the author(s). 


\title{
The Great Convergence? Gender and Unpaid Work in Europe and the United States
}

Ariane Pailhé, Anne Solaz \& Maria Stanfors

\begin{abstract}
Over the past decades, men's and women's time use has changed dramatically suggesting a gender revolution across industrialized nations. Women increased their time in paid work and reduced time in unpaid activities. Men increased their time in unpaid work, but not enough to compensate. Thus, women still perform more unpaid work irrespective of context. We investigate developments regarding men's and women's unpaid work across Europe and the United States, using time diary data from the mid-1980s and onwards. We find evidence for gender convergence in unpaid work over time, but different trends for housework and childcare. Gender convergence in housework was primarily a result from women reducing their time, whereas childcare time increased for both genders only supporting convergence in contexts where men changed more than women. Decomposition analyses show that trends in housework and childcare are generally explained by changes in behaviour rather than compositional changes in population characteristics.
\end{abstract}

\section{Affiliations}

Ariane Pailhé and Anne Solaz : Institut national d'études démographiques (INED) Maria Stanfors : Centre for Economic Demography, Lund University 
From a long-term perspective, men's and women's time use has changed dramatically. One of the most comprehensive changes taking place across Western nations in the past century has been the increase in female labour force participation particularly that of married women and mothers with young children (Goldin 1990, 1995, 2006). Since the 1960s, women's economic roles have fundamentally changed in that paid work has become a natural component throughout the life course instead of just a brief spell determined by age and civil status. While women's paid work has increased, there has been a decrease in male labour force participation since young men have spent more time in education and older men have retired earlier. These developments have led to a convergence in labour force participation rates and the time spent by men and women in paid work (Gershuny 2000) and can be seen as the first stage in the gender revolution (Goldscheider et al. 2015; Stanfors \& Goldscheider 2017).

Increases in women's paid work have meant changes in their engagement in unpaid activities. The time spent by women on home production has decreased substantially thanks to productivity increases through the spread of electrical appliances that have revolutionized domestic work (Greenwood et al. 2005) ${ }^{1}$, but is most likely also due to changing norms. In many countries, men increased their time in home production, albeit starting from very low levels (Bianchi et al. 2000; Coltrane 2000). The changing time use patterns of men and women in both paid and unpaid work support gender convergence (Gershuny 2000; Kan et al. 2011; Leopold et al. 2018). Gender convergence has, however, been asymmetric in that women's time allocation has changed more than men's (Bianchi 2000; Sayer 2005; Bianchi et al. 2006; Stanfors \& Goldscheider 2017). Moreover, women's time in unpaid work did not decline enough to compensate for the larger increase in their paid work time (Bianchi 2000) even when seen in combination with men's increased time in unpaid work which occurred later (Stanfors \& Goldscheider 2017). Still, even if they are employed, women spend more 
time on both housework and childcare than do men (Hook 2006; Lachance-Grzela \& Bouchard 2010; Sayer 2010). Proponents of convergence, however, argue that the gender revolution is still taking place and spreading because men and women have adopted more gender-equal ideals and adapted to a less traditional division of labour and less genderspecialized use of time. Men's, and particularly fathers', increasing involvement in unpaid work since 1990 can thus be seen as the second stage of the ongoing gender revolution (Goldscheider et al. 2015; Altintas \& Sullivan 2016; Stanfors \& Goldscheider 2017).

Though trends towards gender convergence across Europe and the United States are quite similar, cross-national studies indicate that level differences in housework and childcare cannot be explained by individual and household factors alone; they are also determined by macro-level factors such as economic development, welfare regimes, and cultural norms (Fuwa 2010; Hook 2010; Neilson \& Stanfors 2014; Altintas \& Sullivan 2017). There is generally more gender equality in housework and childcare in countries with higher levels of female labour force participation, greater provision of publicly funded childcare, parental leave rather than maternity leave programmes, and more egalitarian gender attitudes (Cooke \& Baxter 2010; Treas \& Drobnic 2010). These patterns may reflect fundamental differences between countries not only in terms of ideologies and institutions supporting full employment irrespective of gender but also in terms of risk-sharing and the role of the family versus the state where interventions are made in the private sphere (i.e. welfare state type and workfamily policy). Analyzing differences across countries therefore helps us understand overall gender inequalities in unpaid work (Bianchi et al. 2012).

The persistent gender differences in unpaid work when seen across countries lead us to ask whether a more equal sharing (i.e. convergence) of such activities is a distant goal. While 
there are economic incentives for both men and women to participate in the labour market, there are no such incentives to engage in unpaid work for which the returns are less clear. The gendering of unpaid activities would even seem to be self-reproducing, which indicates that norms and behaviours are slow to adapt to comprehensive changes in the labour market and in the qualifications held by men and women. The fact that men are generally more likely to increase time with children (Gauthier et al. 2004; Sayer et al. 2004; Neilson \& Stanfors 2014) than housework time leads us to believe that the answer to our question regarding gender convergence in unpaid work might be different if we consider only housework or childcare or the two combined. The answer to our question may also depend on which country we study.

In this paper, we investigate men's and women's time in unpaid work across Europe and the United States since the mid-1980s. First, we describe the long-term development of men's and women's involvement in both housework and childcare in a number of industrialized countries. Second, we analyze the factors that explain men's and women's time in unpaid work by disentangling the factors working for or against gender convergence in housework and childcare. More specifically, we ask whether change is due to compositional changes in the population (i.e. education, employment, family structure) or whether it is driven by behavioural and normative changes. We compare six countries with different levels of female labour force participation, policy ambitions regarding gender equality, and also different cultural norms. The countries explored are Sweden, France, the Netherlands, Italy, the UK, and the United States. The Nordic countries are usually perceived as frontrunners when it comes to gender equality, while the more conservative continental and southern European countries and the United States follow behind in this respect. The comparative approach allows us to assess how country-specific factors influence men's and women's time in unpaid work and is gender convergence can be observed across countries. 
The present work is inspired by the seminal paper of Bianchi et al. (2000) that assessed trends in housework in the United States between the mid-1960s and the mid-1980s, and is an update, an extension, and an elaboration of this. We have analyzed the trends over the past decades, between the mid-1980s and the early 2010s, using several time use surveys and recent data. We have extended the geographical scope to include six countries (five in Europe plus the United States) in order to analyze the role of individual factors from a comparative perspective. The countries studied make up contexts that differ with respect to macro factors such as public policies, social norms and gender relations in the labour market, making the assumption that these factors shape the way men and women take on responsibilities in the labour market and in the home. We have elaborated on the outcome variable and include childcare as a separate category that together with housework make up the lion's share of men's and women's unpaid work. The inclusion of childcare in the analysis is also motivated by the trend towards intensive parenting since the 1980s (Hays 1996; Lareau 2003).

\section{Background}

The gender division of labour and the question of why women spend more time than men on unpaid work - including housework and care for children and others - is a topic that has received much attention from scholars across the social sciences (e.g. Becker 1965, 1985; Oakley 1974; Berk 1985; Hakim 2000; Akerlof \& Kranton 2000; Baker \& Jacobsen 2007; Stratton 2012). The question of why there are gender differences in unpaid work has become more, not less, relevant in present-day contexts where men's and women's qualifications and labour market participation have converged, more people are embracing gender equality, and policies and institutions (at least in some countries) actively support the selfsame, yet where differences in unpaid work persist. In theory, and at the individual level, the debate stands 
between whether women do more unpaid work because they are systematically different from men in terms of characteristics and whether they do more unpaid work because they are behaving in line with gender norms and social pressure arising from unequal power structures in partnerships and in society.

Specialization, bargaining and relative resources

Becker (1965) modelled choice relating to the allocation of time between partners in paid and unpaid work as being determined by the returns from specialization and trade within marriage with the goal of maximizing joint family utility. In this process, partners draw on their comparative advantages in the labour market and in the home. Thus men, who typically have higher earnings potential than women (and a comparative advantage in the labour market), do most of the paid work and women do most of the unpaid work, including housework and childcare. This explanation fits well with the historical narrative, but also implies that if men and women become more equal with respect to human capital determining their earnings potential, we should observe a more equal division of labour whereby men and women do more similar amounts of paid and unpaid work. The model could even result in reverse or gender-neutral specialization. A stronger position of women in the labour market should speed up gender convergence in unpaid work.

Bargaining models, which were a reaction to consensus-based specialization (Manser \& Brown 1980; Lundberg \& Pollak 1996), end up with the same predictions as specialization theory, but through different mechanisms. The bargaining literature has suggested that the more outside options an individual has, the more influence over time allocation decisions (Lundberg \& Pollak 1996). This implies that higher earnings potentials improve women's bargaining power, resulting in more gender-equal time allocations over time. A key element 
of the bargaining models is, however, that those who bargain want to bargain away something. This is understandable in the case of housework but less so for childcare, which many men and women enjoy more than other tasks (Sullivan 2013). Relative resource theory, which is similar to bargaining, also considers housework undesirable, prompting spouses to negotiate lesser quantities for themselves by leveraging their relative resources of education and earnings (Blood \& Wolfe 1960; Brines 1993; Shelton \& John 1996). With improved relative resources, women are now more likely to transfer less desirable tasks to others, including their partners. This would lead to more rapid gender convergence in unpaid work, especially in housework, if men increased their time in addition to women decreasing their.

\section{Gender ideology}

The gender ideology perspective assumes that men and women are affected by societal norms and values, socialized into different gender roles, and contribute to what is normative on the basis of their behavior, which can either confirm or reject prevailing norms and power relations (Berk 1985; West \& Zimmerman 1987; Brines 1994). Women's greater involvement in housework and child-related activities may thus be related to 'doing gender'(i.e. reproducing gendered power relations) or affirming gender identity (Akerlof \& Kranton 2000). Individual-level ideals in favour of more equal role sharing can be outmoded by macro-level gender inequality that slows down gender convergence.

\section{Institutional factors}

Evidence suggests that the degree to which men and women specialize in paid and unpaid work varies across countries (Gauthier et al. 2004). Macro-level explanations emphasize that structural and cultural factors shape the way men and women take on responsibilities in the labour market and in the home (Fuwa 2004; Geist 2005). Some argue that between-country 
variation in gender divisions of labour depends on welfare regime (Sullivan \& Gershuny 2001; Altintas \& Sullivan 2017) and work-family policies available (Hook 2006; Anxo et al. 2011). Commitment to the dual-earner model and family support policies can influence patterns in the gender division of labour. The aim, scope and orientation of such policies differ with welfare regime type. Esping-Andersen's (1990) typology of Western nations features three ideal-types according to a logic that rests on the way in which the welfare state distributes social risks and on what the roles of the state, market, family and the individual are. In brief, in Conservative countries (often in Continental Europe), social rights are selective, and the family together with the Church and the workplace are important welfare providers. In liberal Anglo-Saxon countries, the provision of welfare is minimal, social rights are modest with strict entitlement rules, market dependence is high and the individual's position in the labour market is central in this respect. In Social Democratic countries such as the Nordics, the state is the main provider of general and universal welfare granted as a right to all individuals. Alternative classifications have added more types to Esping-Andersen's original typology (Arts \& Gelissen 2002). One is a Southern (European) model characterized by strong familialism, low social expenditure and the lack of an articulated social minimum of benefits. Hybrid cases have also been identified, such as the Netherlands, which combine features from the Social Democratic and Liberal regime types.

The welfare state regime typology is also a useful framework for exploring gender relations across contexts. ${ }^{2}$ The Social Democratic countries were early adopters of gender-neutral policies and the so-called dual-earner/dual-carer model, which eases work-family conflicts by reducing constraints through a package of parental leave programmes with high levels of income replacement, reduced working hours for parents, family income support, and publicly provided (highly subsidized) childcare (Gornick \& Meyers 2003). Such policies can not only 
increase female, and especially maternal, employment, but they can also affect men's involvement in domestic activities (Hook 2006). Conservative and Liberal welfare states are more selective and less oriented towards reducing gender inequalities. They are more committed towards male breadwinning, resulting in a stricter gender division of labour with lower levels of female labour force participation and less involvement of men in unpaid work (Neilson \& Stanfors 2014). Compared to the Social Democratic countries, policies are restrictive in Liberal welfare states and more generous yet gendered in Corporatist countries. In Southern European countries, policies are both restrictive and gendered and issues regarding gender equality do not rank high on the political agenda.

\section{This study: Gender and Unpaid Work in Europe and the United States}

We have investigated the division of unpaid work between men and women in France, Italy, the Netherlands, the UK, Sweden, and the United States. All countries rank highly on the Human Development Index and receive low values on the Gender Inequality Index (GGGI), which indicates very high levels of human development and little gender inequality as regards achievement in the areas of reproductive health, empowerment and the labour market (UNDP 2016; World Economic Forum 2018). The GGGI measures the gap between men and women in health, education, the economy and politics, focusing on gaps - not levels - in outcomes rather than gaps in inputs. It ranks countries in terms of gender equality rather than women's empowerment. Since the mid-2000s, Sweden (together with three other Nordic countries) has been among the top four performers (Table 1). France, the Netherlands and the UK are among the top twenty and ranked close to each other in 2015 , while the United States and Italy have a lower ranking (numbers 28 and 41 respectively). Of note, both France and Italy considerably improved their ranking as of 2006 when they were both ranked seventieth. 
Table 1 here

Other indicators presented in Table 1 have been selected to illustrate salient differences between countries of relevance for our study. In alignment with the theoretical discussion above, we have chosen labour market indicators to illustrate the degree of specialization between men and women. These measures show men's and women's involvement in paid work. We show indicators of welfare state regime in order to illustrate institutional differences between countries in terms of their commitment to dual earning through state support facilitating the combination of paid and unpaid work and commitment to genderneutral parenthood. Finally, we present some demographic indicators.

Table 1 shows that men are more involved in paid work than women across contexts. Female labour force participation is trending upwards across countries, resulting in gender convergence. Women are, however, more likely to work part-time across contexts. The relative positions of countries with respect to the position of women in the labour market have been stable over time. From the mid-1980s, female labour force participation has been highest in Sweden. It increased sharply in the Netherlands, partly due to extensive part-time employment, though women's participation in paid work also made considerable progress in France, Italy and the UK. Table 1 indicates variation in the degree of specialization across contexts: less so in Sweden compared to other countries, and mostly so in Italy.

The countries investigated represent different welfare regimes: Sweden serves as an example of a Social Democratic welfare state, France represents the European Conservative model, the UK and the United States belong to the liberal Anglo-Saxon model, and Italy is an example of the Southern Model. The Netherlands, as noted above, is a hybrid case. The countries 
explored possess distinguishable macro-level policy mixes, especially when considering the generosity and design of policies that reconcile work-family conflicts, facilitate mothers' employment and encourage men's involvement in domestic activities. Public expenditures on family benefits have been high in the UK, France and Sweden from the mid-1980s, although there is variation in the extent to which these expenditures have been directed towards cash benefits or subsidies (which has a bearing on the in-home or institutionalized daycare of children). Hence, childcare provision for young children is more extensive in France and Sweden than in the UK, as illustrated by the childcare enrolment rates for young children. Public spending on family benefits is very low in the United States, where childcare is mainly private and statutory paid leave does not exist. Paid leave for women varies substantially across Europe with respect to duration, with most extensive entitlements in France. The way men are perceived as carers also varies with much more paid leave being reserved for fathers in France and Sweden than elsewhere. ${ }^{3}$ Childcare enrolment rates for very young children vary more across countries than they do for children aged 3-5. When it comes to state support for families and how that might impact the division of labour between men and women, the combination of measures applied has been the important factor. All this considered, Sweden and France mark themselves as providing comprehensive (though qualitatively different) support for families, while Italy and the United States rank the lowest in this respect.

As for gender ideology, gender role attitudes have become less traditional, and more egalitarian, in all study countries, though cross-country differences persist (Table 2). We show indicators reflecting the norms regarding the division of labour on the basis of the responses given on male and dual breadwinning; on whether it is perceived as harmful to young children that their mother works; and on whether fathers' involvement in child and home care is accepted. When it comes to norms reflecting gender equality, the ranking of countries is 
similar to that of the GGGI in that dual earning is most commonly accepted in Sweden and least accepted in Italy and the Netherlands. There is a surprising difference in attitudes regarding working mothers and the idea that this could be harmful to children, in that respondents in the UK and USA are much more likely to disagree with this perception than are respondents elsewhere. Respondents in the UK are also very accepting of fathers' involvement in child and home care. Furthermore, they are in agreement with the respondents in France and Sweden in believing that men and women should share equal responsibility for family tasks and that fathers are as well suited for looking after children. ${ }^{4}$ Values, however, provide a fuzzier picture than other indicators.

Table 2 here

\section{Hypotheses}

In line with the preceding discussions on theory and national context, we make the following conjectures. The theoretical approaches all involve assumed impacts on the division of unpaid work between men and women. It is expected that women's increased human capital and orientation towards paid work will reduce their time in unpaid work. More outside options and rising female labour force participation over time should also affect women's unpaid work time through increased bargaining power, enabling women to bargain away housework or set a new (lower) standard for it. This should imply that men increase their inputs within the domestic sphere. More emphasis on gender equality and egalitarian gender roles in the labour market and in the home should also imply a reduction of women's unpaid work over time while men's time in housework and childcare should increase. Thus, we expect gender convergence over time in housework and childcare across national contexts (H1). 
Convergence may come from women reducing their unpaid work time, or from men doing more unpaid work, or it may come from change on behalf of both men and women. We expect women to be the main actors of change over time across contexts because they are more affected by changes in the labour market and in the scope of policies supporting the combination of work and family. We expect changes in housework (a decrease) to be most salient among women (H2). We expect changes in childcare (an increase) to be bigger than changes in the time spent on housework among men (H3) because there are widespread ideas about active fathering, trends towards intensive parenting, and more policies supporting gender-neutral parenting than there is support for an equal sharing of housework.

We expect the degree of gender convergence in unpaid work to vary across national contexts (H4), reflecting different orientation towards the dual earner/dual carer model; for example through family benefits, leave policies and provision of (public) childcare. We expect national context to be more important for change in men's involvement in childcare than in housework (H5). Gender convergence seems to be developing along regime type lines, with Liberal and, in particular, Social Democratic countries showing a relatively faster and earlier trend convergence than their Conservative counterparts. One early indicator that the gender division of labour is becoming more gender-neutral is that men are performing more childcare as a way into the domestic sphere (Craig \& Mullan 2010; Hook \& Wolfe 2012; Sayer \& Gornick 2012; Stanfors \& Goldscheider 2017). In this respect, individuals may be more or less constrained in their time allocation choices by the regime type in question. We anticipate that unpaid work time is converging along gender lines across Europe and the United States, but that there are still gender differences in line with specialization across countries, potentially with the exception of Sweden, which is a well-known forerunner when it comes to gender equality, not least among parents (Dribe \& Stanfors 2009). Countervailing factors such as low 
spending on family benefits and low childcare enrolment may hinder gender equality in the domestic sphere, implying that there should be a more traditional division of labour in Continental Europe and the Anglo-Saxon countries compared to Sweden.

Theories about specialization and bargaining/relative resources emphasize that changes in women's human capital and employment are important determinants of changes in unpaid work. Gender ideology, in contrast, stresses the role of changing norms. Institutional factors are important for supporting change in characteristics and work orientation, but also for supporting change in norms and values regarding gender equality. We have good reason to believe that change over time is partly determined by compositional factors since there have been great advances in (particularly women's) education, work patterns, and change in family structure; however, there have also been dramatic changes in norms that are perhaps independent of advances in human capital and family lifestyle. We thus remain agnostic as to whether change is primarily determined by observable characteristics that we can control for or by changing behaviour and norms. To the extent that changing norms and practices provide the main explanation, we expect this to be the case primarily in Sweden (H6).

\section{Data}

Time-use surveys are good sources of information on time measures and allow cross-country comparisons (Juster \& Stafford 1991). They provide particularly reliable information if based on the time diary technique, whereby individuals report their time use over a 24-hour period at ten or fifteen-minute intervals. We have selected two surveys for each study country: one for the mid-1980s (or the earliest available) and one for the 2010s (or the latest available, see Table 3 for survey details). We have thus used data from twelve time diary surveys from France (1985/86 and 2009/10), Italy (1988/89 and 2008/09), the Netherlands (1985 and 2005), 
the UK (1983/84 ${ }^{1}$ and 2014/15²), Sweden (1990/91 and 2010/11), and the United States (1985 and 2006) ${ }^{5}$. Each sample is nationally representative. Weights control for over- and undersampling of certain population groups and interview days. The surveys present some differences in the sample design, existence and number of precoded activities, the length of the time slot and the number of daily diaries. However, these methodological differences should not be a source of significant bias in our analysis since time diary data is generally robust to variation in data collection (Sayer 2010). Importantly, the coding of the two groups of activities focused on in our analysis is very similar across countries and over time. We have analyzed both weekday and weekend entries for each country. All surveys include information on the demographic and socioeconomic situation of individuals and households.

Table 3 here

Sample

For each country we selected a sample of working age (20-60) men and women who completed time diaries. Respondents all belong to one-family households that do not include kin and others. Individuals older than 60 years were excluded because of their specificity in terms of employment status (often retired), health and family structure (usually alone as a couple) correlated with time allocation. The analysis of childcare included only individuals with at least one child under 18 in the household. Sample sizes are reported in Table 4.

\footnotetext{
${ }^{1}$ Social and Community Planning Research and University of Sussex. Science Policy Research Unit, Study of Activities and Time Use, 1983 [computer file]. Colchester, Essex: UK Data Archive [distributor], September 1988. SN: 2170, http://dx.doi.org/10.5255/UKDA-SN-2170-1.

${ }^{2}$ Gershuny, J., Sullivan, O. (2017). United Kingdom Time Use Survey, 2014-2015. Centre for Time Use Research, University of Oxford. [data collection]. UK Data Service. SN: 8128, http://doi.org/10.5255/UKDA-SN-8128-1
} 
Table 4 about here

\section{Measures}

Two broad time use categories consisting of unpaid work activities - housework and childcare - were constructed to serve as our main dependent variables. The aggregated measures are based on main activities reported in individual diaries. Housework includes activities done around the house on a daily basis. The category includes routine tasks such as cooking, washing up, cleaning and laundry (including care of clothes), and maintenance activities that are performed less often, such as home repairs and gardening, and can be scheduled to fit in with other commitments more easily than routine housework. Other activities included are shopping, bookkeeping and household administration tasks, care for adult family members and travel (for performing duties). Childcare includes a range of activities directly aimed at children in the household, such as routine tasks including nappy changing, dressing, feeding and bathing, as well as interactive activities such as supervising homework, reading, talking, playing and attending child activities outside the home. The category also includes time for transport related to children's activities.

All analyses were undertaken separately by country and by gender, and include the same set of demographic and socioeconomic characteristics of potential importance for time in unpaid work. The controls include respondent's age (20-29, 30-39, 40-49 or 50-60), whether the individual was living in a couple (married or cohabiting), the number of child(ren) in the household, whether there was a young child (preschooler) in the household, respondent's level of education, and employment status. Educational attainment has been harmonized in three categories: low (i.e. lower than secondary education), medium (i.e. completed secondary education) and high, which implies post-secondary studies. Employment status include: in 
employment, unemployed, student, homemaker, or for another reason outside the labour market. A dummy indicates part-time work. Finally, because time use varies over the week, a dummy variable for weekend day has been included in the model.

\section{Methods}

Our analysis includes a descriptive part on trends in average housework and childcare time for men and women across Europe and the United States, starting in the mid-1980s with the goal to establish whether there has been gender convergence over the recent decades. To investigate which factors explain change in the time men and women devote to housework and childcare, and to further investigate time period differences, we employed an OaxacaBlinder decomposition (Blinder 1973; Oaxaca 1973). This method allows us to partition change in our dependent variables between the mid-1980s and 2010s into two components; the contribution due to changes in the population, and that which is behavioural or unexplained by changes in population characteristics measured by the explanatory variables. This approach is relevant because observed changes over the past decades in time devoted to housework and childcare time may well be driven compositionally, but also be behavioural, or driven by some combination of composition and behaviour. To investigate what was the case, we pooled the two surveys for each country, and performed decompositions on differences over our study period for dependent variables, separately by gender. This method first estimated linear regressions:

$$
\begin{gathered}
T_{\mathrm{t}+1}=\alpha_{t+1}+\beta_{t+1} \mathbf{X}_{t+1}+\varepsilon \\
T_{\mathrm{t}}=\alpha_{t}+\beta_{t} \mathbf{X}_{t}+\varepsilon
\end{gathered}
$$

Whereby $T$ represented our dependent variable, $\beta$ represented the coefficients, $\mathbf{X}$ is a vector of time use determinants, $\varepsilon$ the error term, and subscripts $t$ and $t+1$ for first and second surveys, 
respectively. Given the average first-stage values, the difference was next decomposed into two components:

$$
\bar{T}_{\mathrm{t}+1}-\bar{T}_{\mathrm{t}}=\left(\alpha_{t+1}-\alpha_{t}\right)+\left(\beta_{t+1}-\beta_{t}\right) \overline{\mathbf{X}}_{t}+\beta_{t+1}\left(\overline{\mathbf{X}}_{t+1}-\overline{\mathbf{X}}_{t}\right)
$$

The between-year difference in mean minutes was decomposed into the amount which we would expect in the last period (2010s), based on first (mid-1980s/1990) sample characteristics (the explained component), $\beta_{t+1}\left(\overline{\mathbf{X}}_{t+1}-\overline{\mathbf{X}}_{t}\right)$ and the amount that is unexplained or behavioral $\left(\beta_{t+1}-\beta_{t}\right) \overline{\mathbf{X}}_{t}$.

\section{Results $^{6}$}

Trends in average time spent on housework and childcare, by sex and country, are illustrated in Figure 1. Table 5 reports the amount of time men and women spent on average on housework per day. There are cross-country differences and similarities regarding housework time. One similarity across countries is that women consistently devoted more time to housework than men. Another similarity is that housework time decreased over time, and so did the difference between men and women. There existed cross-country level differences in the amount of housework women did during the diary day. In the 1980-1990s, women in Sweden and USA spent more than three hours per day on housework, women in France and the UK did around four hours of daily housework, while women in Italy and the Netherlands devoted more than five hours per day to housework. Because almost all women performed housework on a daily basis, there were little differences between average time for all and average time conditional on participation. In 2005-15, women in Sweden, the UK and USA spent three hours or less per day on housework, women in France and the Netherlands did somewhat more, while women in Italy still did considerably more, almost five hours per day, housework. There were more variation between average time for all and average time conditional on participation in the 2000 s due to a slight increase in female non-participation. 
Cross-country differences were more limited when it comes to men's housework time, in actual minutes, which ranged a more limited span (basically between one and two hours among all and around two hours conditional on participation). Men in the Netherlands, Sweden and France, on average, spent more time per day on housework than did men in the other contexts, with men in Italy doing least housework counted in minutes. In the 19801990s, the pattern held up when conditioning on participation, but in 2005-2015, the ordering of countries with respect to men's average housework time changed when looking at participants only. In countries like Italy and, to some extent, France, there was a polarization of behaviours between men who were very involved in housework and men who did no housework. Moreover, there was considerably more variation over time among men's housework time in Italy than elserwhere.

Figure 1 and Table 5 about here

In all study countries, the time spent on housework decreased over the decades studied, especially for women who cut down on their housework hours by $20-25$ percent in all countries except for Italy. ${ }^{7}$ This decline is, however, lower compared to that observed during the 1960s and 1970s in the United States (Bianchi et al. 2000). Women's reduction of time in housework during the period that we study was not compensated for by men's increase in housework time. While American men doubled their housework hours between the 1960s and the 1990s, their time in housework actually decreased between 1985 and 2006, indicating a gender convergence that has stalled as if the men have reached the limit of housework. When it comes to men's average time in housework in Europe, there was also a decrease in the Netherlands, while there was a significant increase in the other countries, especially among 
participants (see France). In Sweden, men's housework time increased between 1990/91 and 2010/11, though their participation rate was stable, which implies a change on the intensive margin. In Italy and the UK, both the proportion of participants and the time spent on housework increased over time. The increase for men, when observed, is always smaller than the decrease observed for women. Thus, men's and women's housework time converged, primarily due to a decrease in women's time women spent on housework. Nevertheless, gender segregation in household tasks still persisted across the contexts studied. Women still performed most of the core housework; i.e. the everyday routine tasks such as meal preparation, cleaning up and laundry, while men did more of the episodic household tasks such as home repairs (see Table A1, cf. Bianchi et al. 2000). Over the last 25 years, changes have been concentrated to the time devoted to routine housework. In particular, the time spent on cooking and cleaning has decreased substantially in all countries, especially for women, likely attributable to time-saving household appliances and changing norms and standards regarding meals and cleanliness.

Like in the case of housework, women consistently devoted more time to childcare than men, but unlike the case of housework, this increase came by both men and women increasing their time devoted to childcare (though not significantly for women in Sweden). Table 6 shows that there was a general increase in participation in childcare among men during the day surveyed. In France, Sweden and the UK, gender differences in absolute childcare time diminished, but in Italy, the Netherlands, and USA, differences between men and women increased (Table 6). Women's share of total childcare time decreased everywhere (except for among participants in Italy). There was thus widespread gender convergence in childcare time, while time spent on this activity increased. ${ }^{8}$ 
Table 6 about here

Childcare was generally more equally shared among men and women than housework. The amount of time spent on childcare was, however, substantially less (about half or less) than the amount of time spent on housework throughout contexts, even among participants (i.e. those who perform the activity during the diary day). Gender differences in daily childcare time were smallest in Sweden, followed by France, USA, the UK, Italy and the Netherlands (generally but also largely conditional on participation). One can only partly understand these gender differences through state support to families, work-family policies, and female labour force participation. When looking at what the men and women did by way of childcare (Table A1), we see that gender differences were driven mainly by routine childcare and to some extent interactive childcare. Over time there has been a general tendency - especially among women - to increase the amount of transport related to children's activities, which is very likely due to higher urbanization, school choice, and more extracurricular activities on the part of the children. Interactive childcare has jumped in the UK, the Netherlands, Italy and the United States, especially for women. The combination of men and women increasing their time in interactive childcare makes a big difference and confirms the change toward timeintensive parenting practices across countries with different policy orientation.

\section{What explains change over time? Decomposition of results}

Housework

Tables 7-8 present the decomposition results of change in average daily housework time for men and women between survey waves, typically between the mid-1980s/1990 and the first decades of the $21^{\text {st }}$ century, while Tables 9-10 present the decomposition results of change in average daily childcare time across Europe and the United States. Figure 2 summarizes the 
results of these decompositions. Complete regression results are available in Appendix A2A7. The first three rows report the average time spent on housework or childcare in the two survey years and the raw difference between the two. This difference is then decomposed into two components, one being the part of the raw time gap explained by differences in observed characteristics of the population, and the other one being the part explained by the difference in the propensity of men and women respectively to do housework or childcare over time. This component is also called the "unexplained part". In other words, the explained part corresponds to a compositional change in the population, while the unexplained part could be interpreted as a behavioural change.

The main regression and decomposition results presented in Table 7 may be summarized as follows. A significant reduction in women's daily housework time - across contexts - ranging from 33 minutes (USA) to 90 minutes (the Netherlands) is explained by a combination of compositional changes in population characteristics and behavioural change in France, Italy, the Netherlands and the UK. The contribution of women's characteristics is particularly marked in the latter two countries where they explain more than half of the change in housework time. In all four countries, change in women's employment status was the main driver of characteristics determining the reduction in housework. Change in women's characteristics does not explain the decrease in housework time in Sweden and not by much in USA where the absolute decreases of housework time were the smallest. In these countries, change in characteristics would actually favour a small increase in the time spent on housework. This difference is, compared to the other countries, mainly due to the fact that female labour force participation was already high in the mid-1980s and remained so. The overall increase in the level of education among women has led, as in the other countries, to a decrease in their housework time, although to a lesser extent. Behavioural change is the main 
explanation for the decrease in women's housework time in France, Sweden, and the United States. For example in the case of France, women's time in housework decreased by 71 minutes between 1985/86 and 2009/10. Only 16 minutes (23\%) can be attributed to changing population characteristics. The rest (77\%) should be related to the behavioral component. In Sweden, change in characteristics had no bearing at all on the decrease in women's housework time; attributing change to behaviour is actually an over-explanation regarding women's housework time. In the United States, changing practices accounted for more than the 33 minute reduction of women's housework time between 1985 and 2006.

Figure 2 and Tables 7-8 about here

For men, the regression and decomposition results presented in Table 8 show that there was an increase in time spent on housework in Italy and the UK, no change in France and Sweden, and a decrease in men's housework time between survey years in the Netherlands and USA. Irrespective of what direction change among men was going, it was mainly explained by changing behaviour and practices in Italy, the Netherlands and USA. In the UK, change was explained by weekday/weekend differences, which is denoted as a change in characteristic but may well reflect behavioural since time use is different during weekdays and weekend days. As found for women, change in men's employment status was an important factor for change in housework time, though not of the same magnitude.

The decomposition results adds information to story of convergence in men's and women's housework time across Europe and the United States. In a way, the story is complex due to cross-country variation in change of the determinants of men's and women's housework time. Change is, however, mainly due to a decrease in women's time spent on housework, and the 
main explanation behind this change is behavioral change, i.e. what we cannot measure directly by means of characteristics included in our model. For some countries in Europe, increasing female labour force partcipation is part of the explanation of women's reduced housework time from the mid-1980s onwards, but not for countries where female labour force participation was high already in the mid-1980s (Sweden and the United States). In the case of men, there is cross-country variation in housework trends, though change is also for men more a matter of behavioural change than change in characteristics.

\section{Childcare}

When it comes to childcare, Table 9 shows that there was an increase in time spent on this activity among women in all countries studied (though not significant for Sweden), ranging from 5 (Sweden) to 50 minutes (Italy) per day. Change in childcare time was behavioural, indicating a trend towards intensive parenting. Further, this increase was most substantial in Italy, the Netherlands, and the United States. Change in characteristics accounts only in small part for the change in mothers' childcare time, and would actually primarily reduce childcare time. Though outmodeled by change in parental practices, the details of the explained part of the difference between survey years show something interesting. Though the increase in female labour force participation tend to reduce mothers' childcare time, the increase in women's education has had the reverse effect because highly educated women devote more time to childcare. In all countries, except for the United States, change in women's education trumps change in employment status. Increasing time with children is also visible in coefficients associated to family structure. Across countries, except for France and Sweden, parents in the early 2000s, did more childcare than similar parents two decades before.

Tables 9-10 about here 
For men, there was a significant increase in time spent on childcare across all countries studied, ranging from 18 minutes per day in the Netherlands to 34 minutes per day in the United States. As for women, this increase in fathers' childcare time was mainly behavioural (the explained part is very limited), which further supports a general trend towards intensive parenting - not only among mothers - though strongest in the United States. Having a preschooler in the household together with other family-related factors generally contributed to the increase in men's childcare time. In Sweden, change to other states than being employed was important for men's childcare time (negative association) indicating different childcare practices relating to employment status. In the United States, as in the case of women, education was important for behaviour and the increase in men's childcare time.

The decomposition results also adds information to story of potential convergence in men's and women's childcare time. The descriptive story was one of gender convergence in absolute time devoted to childcare on a daily basis in France, Sweden and the UK where men's childcare time increased more than women's. It was also a story of divergence in Italy, the Netherlands, and the United States because, in these countries, women's childcare time increased even more than men's though starting from much higher levels. In all countries studied, both men and women changed their behaviours (convergence across countries and gender in spending more time on childcare) but change was more comprehensive among women than among men in Italy, the Netherlands, and USA thus working against gender convergence in childcare time. 


\section{Concluding discussion}

Despite of a dramatic increase in women's paid work, women continue to perform the majority of unpaid work. We set out to analyze the trends of level shifts and gender differences in housework and childcare across Europe and the United States over the past decades. We looked for gender convergence and found indications of it both when it comes to housework and childcare. Consistent with our first hypothesis and previous research (Altintas \&. \& Sullivan 2016; Bianchi et al. 2006; Kan et al. 2011; Stanfors \& Goldscheider 2017; Leopold et al. 2018), we found that men's and women's time use has tended to converge, but that is primarily due to a decrease in women's housework time, especially time spent cooking. After the sizeable decline between 1965 and 1985, the time American men spent on housework remained constant between 1985 and 2006. Also, in some European countries, such as France and Sweden, men's time in housework remained stable, or even decreased as in the Netherlands. Though, the relative contribution of women to the total amount of housework has slightly decreased during the past 25-30 years, they still mostly perform the routine, "female-typed" tasks. Gender differences in housework time thus persist in both quantative and qualitative terms. While women everywhere has been doing less housework, men in Sweden have been picking up the slack more than elsewhere with more convergence in housework as a result.

For childcare we observed something different. The tendency over past decades has been to do more childcare, irrespective of gender, even though there are several factors that in theory suggest the opposite (e.g. population becoming better educated and more work-oriented, expansion of childcare services, individualization). Everyone has been devoting more time to children except for women in Sweden who have marginally reduced their time by a few minutes. In France, Sweden and the UK, men have increased their childcare time more than 
have women, while in the United States absolute growth is similar for men and women, and in Italy and the Netherlands it is higher for women. Nevertheless, women's share of total childcare decreased across our study countries. Thus, we found gender convergence over time in housework and childcare across national contexts (H1). Convergence mainly came from women changing time use, for example reducing housework time $(\mathrm{H} 2)$. In line with expectations, changes in men's childcare time were more salient than changes in their time spent on housework (H3). Men's increased childcare time was, however, largely superseded by women's increased childcare time, particularly in the United States.

We observed different patterns of gender convergence in unpaid work across countries, largely in line with expectations (H4). We found more gender convergence, in both housework and childcare, in Sweden than elsewhere, though the country was well-projected in gender equality already in 1990. Italy consistently lagged in terms of gender convergence. Our results suggest that a country's orientation towards dual-earning and dual-caring matter for both housework and childcare time, though more ambitious family benefits, leave policies and provision of public childcare matter for gender convergence in childcare time. Contrary to hypothesis H5, national context was less important for change in men's involvement in childcare than in housework as fathers' childcare time increased everywhere.

We also wanted to find out whether the trends we see in housework and childcare were driven by changes in characteristics or by changes in behaviours and norms among men and women in the study contexts. The decomposition analysis showed that changes in the time spent on housework and childcare were mainly explained by changes in behaviour rather than changes in characteristics of the populations studied. This was the case for both men and women. When it comes to characteristics of importance for change, increased education and work 
orientation among women significantly contributed to reducing the time women devote to housework on a daily basis in many contexts. Increases in men's and women's level of education also contributed to explaining the increase in childcare time for both men and women, except for in the United States where this was entirely behavioural and quite unrelated to compositional changes. Though there is a general tendency towards intensive parenting, this is strongest in the United States, in particular among men and women with a post-secondary education.

Changing practices and norms largely explain changes in housework and childcare across industrialized nations. Several factors may have accounted for the decrease in housework intensity. First, there has been greater opportunity to outsource housework. Greater use of quick-to-prepare substitutes or ready-made food and more frequent eating out have significantly reduced the time spent cooking. Housekeeping services have also grown in importance, and women do not mend clothes when they can buy cheap new ones. Second, technological progress in home equipment or domestic products may have helped reduce housework time, even though the productivity achieved by the "domestic revolution" that occurred mainly before the eighties has seen a serious drop over the last 25 years. Third, behavioural trends are probably due to a decrease in the standards of home cleanliness or the composition of meals over time. The low participation of men in housework and the tight time squeeze endured by women may have led the latter to review their standard of housework and invest less time in housecleaning and cooking. Men have been happy to accept lower standards of housework, and women still do the bulk of it. Changes in standards have also affected childcare, but in the opposite way. New norms about parenthood have emerged. More time and attention have been directed at the child because parental investment is now considered a necessity, one of benefit for a child's development. To this end, men and women 
belonging to the educated middle class have been the leaders of change towards intensive parenting, concerted cultivation, and investment in the child's human capital.

Regarding the cross-country differences we observe regarding levels, trends, and gender differencess in unpaid work, much is in line with expectations of how men's and women's housework and childcare time correlate with welfare state regime and macro-level indicators of relevance for gender equality. Sweden is a frontrunner, and in France, the UK and USA gender differences in housework and childcare are smaller than in Italy and the Netherlands. This range of countries, with Sweden taking the lead towards a more equal sharing of unpaid work, gives us an idea of what may work well in promoting gender equality. High female labour force participation and a relatively small wage gap support female economic independence. Public spending on family services, such as subsidized childcare, makes the combination of paid work and family possible for all women. A society in which women can take on a more independent role as breadwinner and provider would bring about a new equilibrium, whereby men too would start changing their behaviours. For men, the change would mean taking on unpaid work. Education and changing family structures have been put forward as key to this, though our results show that change in housework and childcare seems to be related more to changing norms and practices. This indicates that gender convergence in housework and childcare is likely to increase further. So does the fact that the long-term trends we observe are more similar than divergent across the countries studied.

\section{References}

Akerlof G. A. \& Kranton, R. E. (2000). Economics and identity. Quarterly Journal of Economics 115(3): 715-753. 
Altintas, E. \& Sullivan, O. (2016). Fifty years of change updated: Cross-national gender convergence in housework, Demographic Research, 35(16): 455-470.

Altintas, E. \& Sullivan, O. (2017). Trends in fathers' contribution to housework and childcare under different welfare policy regimes, Social Politics, 24(1): 81-108.

Anxo, D., Flood L., Mencarini, L., Pailhé, A., Solaz, A. \& Tanturri, M.L. (2011). Gender differences in time use over the life course in France, Italy, Sweden, and the US. Feminist Economics, 17(3): 159-195.

Arts, W. \& Gelissen, J. (2002). Three worlds of welfare capitalism or more? A state-of-the-art report. Journal of European Social Policy, 12(2): 137-158.

Baker, M. J. \& Jacobsen, J. P. (2007). Marriage, specialization, and the gender division of labor. Journal of Labor Economics 25(4): 763-793.

Becker, G. (1965). A theory of the allocation of time. Economic Journal 75: 493-517.

Becker, G. (1985). Human capital, effort, and the sexual division of labor. Journal of Labor Economics 3(1): 33-58.

Berk, S.F. (1985). The Gender Factory: The Apportionment of Work in American Households. New York: Plenum.

Bianchi, S. M. (2000). Maternal employment and time with children: Dramatic change or surprising continuity? Demography 37(4): 401-414.

Bianchi, S. M., Robinson, J. P. \& Milkie, M. A. (2006). Changing Rhythms of American Family Life. New York: Russell Sage Foundation.

Bianchi, S., Sayer, L., Milkie, M. \& Robinson, J. (2000). Is anyone doing the housework? Trends in the gender division of household labor. Social Forces 79(1): 191-228.

Bianchi, S., Sayer, L., Milkie, M. \& Robinson, J. (2012). Housework: Who did, does, or will do it and how much does it matter? Social Forces, 91(1): 55-63. 
Blinder, A. S. (1973). Wage discrimination: Reduced form and structural estimates. Journal of Human Resources 8(4): 436-55.

Blood, R. O. \& Wolfe, D. M. (1960). Husbands and Wives: The Dynamics of Married Living. Glencoe: Free Press.

Brines, J. (1993). The exchange value of housework. Rationality and Society 5(3): 302-340.

Brines, J. (1994). Economic dependency, gender, and the division of labor at home. American Journal of Sociology 100(3): 652-688.

Coltrane, S. (2000). Research on household labor: Modeling and measuring the social embeddedness of routine family work. Journal of Marriage and Family, 62(4), 12081233.

Cooke, L. \& Baxter, J. (2010). “Families” in international context: Comparing institutional effects across Western societies. Journal of Marriage and Family 72(3): 516-36.

Craig, L. \& Mullan, K. (2010). Parenthood, gender and work-family time in the United States, Australia, Italy, France and Denmark. Journal of Marriage and Family 72(4): 13441361.

Dribe, M. \& Stanfors, M. (2009). Does parenthood strengthen a traditional household division of labor? Evidence from Sweden. Journal of Marriage and Family 71(1): 33 45.

Esping-Andersen, G. (1990). The Three Worlds of Welfare Capitalism. Cambridge: Polity Press.

Fuwa, M. (2004). Macro-level gender inequality and the division of household labor in 22 countries. American Sociological Review 69(6): 751-767.

Gauthier, A., Smeeding, T. M. \& Furstenberg, F. F. Jr. (2004). Are parents investing less time in children? Trends in selected industrialized countries. Population and Development Review 30(4): 647-671. 
Geist, C. (2005). The welfare state and the home: Regime differences in the domestic division of labor. European Sociological Review 21(1): 23-41.

Gershuny, J. (2000). Changing Times: Work and Leisure in Postindustrial Society. Oxford: Oxford University Press.

Gershuny, J. (2004). Domestic equipment does not increase domestic work: A response to Bittman, Rice and Wajcman. British Journal of Sociology 55(3): 425-431.

Gershuny, J. \& Sullivan, O. (2003). Time use, gender, and public policy regimes. Social Politics 10(2): 205-228.

Goldin, C. (1990). Understanding the Gender Gap: An Economic History of American Women. New York: Oxford University Press.

Goldin, C. (1995). The U-shaped female labor force function in economic development and economic history. In Schultz, T. P. (Ed). Investment in Women's Human Capital. Chicago: University of Chicago Press, 61-90.

Goldin, C. (2006). The quiet revolution that transformed women's employment, education and family. The American Economic Review Papers and Proceedings 96(1): 1-21.

Goldscheider, F., Bernhardt, E. \& Lappegård, T. (2015). The gender revolution: A theoretical framework for understanding changing family and demographic behavior. Population and Development Review 41(2): 207-239.

Gornick, J. C. \& Meyers, M. (2003). Families that Work: Policies for Reconciling Parenthood and Employment. New York: Russell Sage.

Greenwood, J., Seshadri, A. \& Yorukoglu, M. (2005). Engines of liberation. Review of Economic Studies 72(1): 109-133.

Hakim C. (2000). Work-Lifestyle Choices in the 21st Century: Preference Theory. Oxford: Oxford University Press. 
Hays, S. (1996). The Cultural Contradictions of Motherhood. New Haven, CT: Yale University Press.

Hook, J. (2006). Care in context: Men's unpaid work in 20 countries, 1965-2003. American Sociological Review 71(4): 639-660.

Hook, J. (2010). Gender inequality in the welfare state: Sex segregation in housework, 19652003. American Journal of Sociology 115(4): 1480-1523.

Hook, J. \& Wolfe, C. (2012). New fathers? Residential fathers' time with children in four countries. Journal of Family Issues 33(4): 415-450.

Juster, F. T. \& Stafford, F. P. (1991). The allocation of time: Empirical findings, behavioral models, and problems and measurement. Journal of Economic Literature 29(2): 471522.

Kan, M. Y., Sullivan, O. \& Gershuny, J. (2011). Gender convergence in domestic work: Discerning the effects of interactional and institutional barriers from large-scale data. Sociology 45(2): 234-251.

Lachance-Grzela, M. \& Bouchard, G. (2010). Why do women do the lion's share of housework? A decade of research. Sex Roles 63(11-12): 767-780.

Lareau, A. (2003). Unequal Childhoods: Class, Race, and Family Life. Ewing, NJ: University of California Press.

Leopold, T., Skopek, J. \& Schulz, F. (2018): Gender convergence in housework time: A life course and cohort perspective. Sociological Science 5: 281-303.

Lundberg, S. \& Pollack, R. (1996). Bargaining and distribution in marriage. Journal of Economic Perspectives 10(4): 139-158.

Manser, M. \& Brown, M. (1977). Bargaining analyses of household decisions. In C. B. Lloyd \& E. S. Andrews (Eds.), Women in the Labor Market. New York: Columbia University Press, 3-26. 
Neilson, J. \& Stanfors, M. (2014). It's about time! Gender, parenthood and household divisions of labor under different welfare regimes. Journal of Family Issues 35(8): 1066-1088.

Oakley, A. (1974). The Sociology of Housework. New York: Pantheon Press.

Oaxaca, R. (1973). Male-female wage differentials in urban labor markets. International Economic Review 14(3): 693-709.

Orloff, A. S. (1993). Gender and the social rights of citizenship: The comparative analysis of state policies and gender relations. American Sociological Review 58(3): 303-328.

Sainsbury, D. (1996). Gender, Equality and Welfare States. Cambridge: Cambridge University Press.

Sayer, L. C. (2010). Trends in housework. In J. Treas \& S. Drobnic (Eds.) Dividing the Domestic: Men, Women, and Household Work in Cross-National Perspective. Palo Alto: Stanford University Press.

Sayer, L. \& Gornick, J. (2012). Cross-national variation in the influence of employment hours on child care time. European Sociological Review 28(4): 421-442.

Sayer, L. C., Bianchi, S. M. \& Robinson, J. P. (2004). Are parents investing less in children? Trends in mothers' and fathers' time with children. American Journal of Sociology 110(1): 1-43.

Shelton, B. A \& John, D. (1996). The division of household labor. Annual Review of Sociology 22: 299-322.

Stanfors, M. \& Goldscheider, F. (2017). The forest and the trees: Industrialization, demographic change, and the ongoing gender revolution in Sweden and the United States, 1870-2010. Demographic Research 36: 173-226.

Stratton, L. S. (2012). The role of preferences and opportunity costs in determining the time allocated to housework. The American Economic Review 102(3): 606-611. 
Sullivan, O. (2013). What do we learn about gender by analyzing housework separately from child care? Some considerations from time-use evidence. Journal of Family Theory \& Review 5(2): 72-84.

Sullivan, O. \& Gershuny, J. (2001). Cross-national changes in time use: Some sociological (hi)stories re-examined. British Journal of Sociology 52(2): 331-347.

Treas, J. \& Drobnic, S. (Eds.) (2010). Dividing the Domestic: Men, Women and Household Work in Cross-National Perspective. Palo Alto: Stanford University Press.

UNDP (2016). Human Development Report. Human Development for Everyone. New York: United Nations.

Vanek, J. (1974). Time spent in housework. Scientific American 5(231): 116-120.

West, C. \& Zimmerman, D. (1987). Doing gender. Gender and Society 1(2): 125-151.

World Economic Forum. (2018). The Global Gender Gap Report 2017. Geneva. 
TABLE 1 Contextual indicators for France, Italy, the Netherlands, Sweden, the UK, and USA.

\begin{tabular}{|c|c|c|c|c|c|c|c|c|c|c|c|c|}
\hline \multirow[b]{2}{*}{ Labour market } & \multicolumn{2}{|c|}{ France } & \multicolumn{2}{|c|}{ Italy } & \multicolumn{2}{|c|}{ Netherlands } & \multicolumn{2}{|c|}{ Sweden } & \multicolumn{2}{|c|}{ UK } & \multicolumn{2}{|c|}{ USA } \\
\hline & 1985 & 2015 & 1985 & 2015 & 1985 & 2015 & 1985 & 2015 & 1985 & 2015 & 1985 & 2015 \\
\hline Female labour force participation rate (15-64) & 55.6 & 67.6 & 40.2 & 54.9 & 40.9 & 74.7 & 79.3 & 79.9 & 62.4 & 72.5 & 64.1 & 66.9 \\
\hline Male labour force participation rate (15-64) & 77.3 & 75.5 & 76.3 & 75.2 & 75.3 & 84.6 & 86.3 & 83.5 & 88.1 & 82.8 & 85.4 & 78.5 \\
\hline Women's share of part-time employment (a) & 82.4 & 78.1 & 72.1 & 73.2 & 74.4 & 70.8 & 77.6 & 67.1 & 80.7 & 73.8 & 68.0 & 64.2 \\
\hline Average usual weekly hours on main job (a) & 36.1 & 36.0 & 37.4 & 35.5 & 30.6 & 29.0 & $36.9(\mathrm{e})$ & 35.8 & 37.1 & 36.6 & 38.9 & 38.6 \\
\hline$\%$ Women working less than 35 hours a week & 25.8 & 30.9 & 22.2 & 42.2 & 54.0 & 77.1 & $45.1(\mathrm{~g})$ & 34.3 & 47.7 & 47.4 & 27.9 & 24.0 \\
\hline$\%$ Men working less than 35 hours a week & 5.8 & 9.3 & 5.0 & 12.0 & 8.4 & 28.3 & $6.7(\mathrm{~g})$ & 15.7 & 6.0 & 15.9 & 10.9 & 11.6 \\
\hline$\%$ Women working more than 40 hours a week & 22.5 & 22.8 & 57.9 & 37.8 & 37.5 & 12.0 & $43.2(\mathrm{~g})$ & 48.5 & 23.9 & 28.6 & 60.5 & 67.4 \\
\hline$\%$ Men working more than 40 hours a week & 40.5 & 41.6 & 49.6 & 79.6 & 76.3 & 50.7 & $84.5(\mathrm{~g})$ & 70.0 & 71.2 & 62.1 & 84.6 & 84.3 \\
\hline \multicolumn{13}{|l|}{ Welfare regime } \\
\hline $\begin{array}{l}\text { Proportion of children } 0-2 \text { years in childcare and } \\
\text { preschool services }(2014)\end{array}$ & na & 51.9 & na & 24.2 & na & 55.9 & na & 46.9 & na & 33.6 & na & 28.0 \\
\hline $\begin{array}{l}\text { Proportion of children } 3-5 \text { years in childcare and } \\
\text { preschool services }(2014)\end{array}$ & na & 100 & na & 95.1 & na & 92.0 & na & 94.3 & na & 93.7 & na & 66.8 \\
\hline $\begin{array}{l}\text { Public spending on family benefits in cash, services } \\
\text { and tax breaks as percent of GDP(b) }\end{array}$ & 2.63 & 3.65 & 0.88 & 1.97 & 2.01 & 1.81 & 3.71 & 3.64 & 2.14 & 3.95 & 0.6 & 1.13 \\
\hline $\begin{array}{l}\text { Total paid leave for women (maternity }+ \text { parental) in } \\
\text { weeks (c) }\end{array}$ & 16 & $42 / 110$ & 47.7 & 47.7 & 12 & 16 & 52 & 60 & 18 & 39 & 0 & 0 \\
\hline Total paid leave reserved for fathers in weeks (c) & 0 & $28 / 54$ & 0 & 0.2 & 0 & 0.4 & 1.4 & 10 & 0 & 2 & 0 & 0 \\
\hline \multicolumn{13}{|l|}{ Gender relations } \\
\hline Rank Global Gender Gap (d) & 70 & 15 & 77 & 41 & 13 & 16 & 1 & 4 & 9 & 18 & 23 & 28 \\
\hline Gender Inequality Index (h) & 18 & 21 & 15 & 26 & 4 & 7 & 1 & 14 & 20 & 16 & 31 & 10 \\
\hline \multicolumn{13}{|l|}{ Demography } \\
\hline Crude divorce rate (divorces per 1,000 people) & 1.9 & 2.1 & 0.3 & 0.9 & 2.3 & 2.1 & 2.4 & 2.7 & 2.8 & 2.0 & 5.0 & 3.2 \\
\hline Total fertility rate (TFR) & 1.81 & 1.92 & 1.45 & 1.35 & 1.51 & 1.66 & 1.73 & 1.85 & 1.79 & 1.80 & 1.84 & 1.84 \\
\hline
\end{tabular}

Note: (a) Earlier data: 2000. (b) Data for 1985 do not include tax-breaks for families. (c) In France: families with one child/two and more children. (d) Earlier data: 2006; (e) 2002: (f) 2012; (g) 1987; (h) 1995.

Source: OECD Employment Database, OECD Family Database, World Economic Forum (2018) 
TABLE 2 Gender norms for France, Italy, the Netherlands, Sweden, the UK, and USA.

\begin{tabular}{|c|c|c|c|c|c|c|c|c|c|c|c|c|c|c|c|c|}
\hline & \multicolumn{3}{|c|}{ France } & \multicolumn{3}{|c|}{ Italy } & \multicolumn{3}{|c|}{ Netherlands } & \multicolumn{3}{|c|}{ Sweden } & \multicolumn{3}{|c|}{ Great Britain } & \multirow{2}{*}{$\begin{array}{c}\text { USA } \\
1990\end{array}$} \\
\hline & 1990 & 1999 & 2008 & 1990 & 1999 & 2009 & 1990 & 1999 & 2008 & 1990 & 1999 & 2009 & 1990 & 1999 & 2009 & \\
\hline $\begin{array}{l}\text { Strongly disagree: Being a housewife } \\
\text { is just as fulfilling as working for pay } \\
\text { (a) }\end{array}$ & 8.5 & 12.8 & 14.5 & 7.9 & 7.7 & 9.5 & 7.4 & 9.5 & 8 & 14.9 & 14.4 & 11.9 & 60.9 & 60.1 & 69.5 & 74.5 \\
\hline $\begin{array}{l}\text { Disagree: When jobs are scarce, men } \\
\text { have more right to a job than women } \\
\text { (b) }\end{array}$ & 58.9 & 68.3 & 84.5 & 47.7 & 56.8 & 67.6 & 69.9 & 83.4 & 85.3 & 87.9 & 93.4 & 97.5 & 35 & 21 & 13.6 & 23.8 \\
\hline $\begin{array}{l}\text { Agree strongly: Both the husband and } \\
\text { wife should contribute to household } \\
\text { income }(a)\end{array}$ & 37.5 & 43.9 & 58.5 & 24 & 24.9 & 28.6 & 8.5 & 7.8 & 9.5 & 60.5 & 57.2 & 44.7 & 53.3 & 45.6 & 37.2 & 51.7 \\
\hline $\begin{array}{l}\text { Strongly disagree: A preschool child } \\
\text { is likely to suffer if his or her mother } \\
\text { works }(a)\end{array}$ & 6.7 & 17.6 & 27.9 & 2.1 & 1.1 & 2.6 & 6 & 12.3 & 15.4 & 9.7 & 28.2 & 31.9 & 72 & 68.9 & 73 & 67 \\
\hline $\begin{array}{l}\text { Agree strongly: Men should take as } \\
\text { much responsibility as women for the } \\
\text { home and children (a) }\end{array}$ & & & 65 & & & 34.7 & & & 23.1 & & & 62.1 & & & 93.7 & \\
\hline $\begin{array}{l}\text { Agree strongly: In general, fathers } \\
\text { are as well suited to look after their } \\
\text { children as mothers }(a)\end{array}$ & & 42.1 & 54.1 & & 16.1 & 18.1 & & 22.4 & 20.6 & & 59.6 & 45 & & 70.8 & 77.3 & \\
\hline
\end{tabular}

Note: Questions were formulated as: a)"People talk about the changing roles of men and women today. For each of the following statements I read out, can you tell me how much you agree with each. Please use the responses on this card. 1 Agree strongly / 2 Agree / 3 Disagree /4 Disagree strongly. b) Do you agree or disagree with the following statements? 1 Agree /2 Disagree /3 Neither.

Source: European Value Survey 1990, 1999 and 2008 (https://zacat.gesis.org/webview/index.jsp?object=http://zacat.gesis.org/obj/fCatalog/Catalog5); World Value Survey 1990 (http://www.worldvaluessurvey.org/wvs.jsp). 
TABLE 3 Information on time use surveys from France, Italy, the Netherlands, Sweden, the UK, and USA.

\begin{tabular}{|c|c|c|c|c|c|c|c|c|c|c|c|c|}
\hline & \multicolumn{2}{|c|}{ France } & \multicolumn{2}{|c|}{ Italy } & \multicolumn{2}{|c|}{ Netherlands } & \multicolumn{2}{|c|}{ Sweden } & \multicolumn{2}{|c|}{ UK } & \multicolumn{2}{|c|}{ USA } \\
\hline $\begin{array}{l}\text { Survey } \\
\text { period }\end{array}$ & $\begin{array}{c}\text { September } \\
1985- \\
\text { September } \\
1986 \\
\text { (8 waves } \\
\text { during 6 } \\
\text { weeks) }\end{array}$ & $\begin{array}{c}\text { September } \\
2009- \\
\text { September } \\
2010\end{array}$ & $\begin{array}{c}\text { June } 1988- \\
\text { May } 89\end{array}$ & $\begin{array}{c}\text { February- } \\
2008 \text { - } \\
\text { January } 09\end{array}$ & $\begin{array}{c}\text { October } \\
1985\end{array}$ & $\begin{array}{c}\text { October } \\
2005\end{array}$ & $\begin{array}{c}\text { September } \\
1990 \text { - May } \\
1991\end{array}$ & $\begin{array}{l}\text { April } 2010 \text { - } \\
\text { March } 2011\end{array}$ & $\begin{array}{c}\text { November } \\
1983- \\
\text { February } \\
1984\end{array}$ & $\begin{array}{c}\text { April } 2014 \text { - } \\
\text { December } \\
2015\end{array}$ & $\begin{array}{c}\text { Whole of } \\
1985\end{array}$ & $\begin{array}{l}\text { Whole of } \\
2006\end{array}$ \\
\hline Collector & $\begin{array}{l}\text { Office for } \\
\text { National } \\
\text { Statistics } \\
\text { (Insee) }\end{array}$ & $\begin{array}{l}\text { Office for } \\
\text { National } \\
\text { Statistics } \\
\text { (Insee) }\end{array}$ & $\begin{array}{l}\text { Office for } \\
\text { National } \\
\text { Statistics } \\
\text { (Istat) }\end{array}$ & $\begin{array}{l}\text { Office for } \\
\text { National } \\
\text { Statistics } \\
\text { (Istat) }\end{array}$ & $\begin{array}{c}\text { Sociaal en } \\
\text { Cultureel } \\
\text { Planbureau }\end{array}$ & $\begin{array}{c}\text { Sociaal en } \\
\text { Cultureel } \\
\text { Planbureau } \\
\& \text { United } \\
\text { Fieldwork } \\
\text { Organisation }\end{array}$ & $\begin{array}{l}\text { Statistics } \\
\text { Sweden }\end{array}$ & $\begin{array}{l}\text { Statistics } \\
\text { Sweden }\end{array}$ & $\begin{array}{l}\text { SCPR, } \\
\text { University } \\
\text { of Bath, } \\
\text { University } \\
\text { of Sussex }\end{array}$ & $\begin{array}{l}\text { Centre for } \\
\text { Time Use } \\
\text { Research, } \\
\text { University } \\
\text { of Oxford }\end{array}$ & $\begin{array}{c}\text { Survey } \\
\text { Research } \\
\text { Center, } \\
\text { University } \\
\text { of Michigan }\end{array}$ & $\begin{array}{l}\text { Bureau of } \\
\text { Labor } \\
\text { Statistics }\end{array}$ \\
\hline Diaries & $\begin{array}{l}1 \text { daily } \\
\text { diary }\end{array}$ & $\begin{array}{l}1 \text { or } 2 \text { daily } \\
\text { diaries (1 } \\
\text { weekday, } 1 \\
\text { weekend } \\
\text { day) }\end{array}$ & $\begin{array}{l}1 \text { daily } \\
\text { diary }\end{array}$ & $\begin{array}{l}1 \text { daily } \\
\text { diary }\end{array}$ & $\begin{array}{l}1 \text { weekly } \\
\text { diary }\end{array}$ & $\begin{array}{l}1 \text { weekly } \\
\text { diary }\end{array}$ & $\begin{array}{c}2 \text { daily } \\
\text { diaries (one } \\
\text { weekday, } \\
\text { one } \\
\text { weekend } \\
\text { day within } \\
\text { two weeks) } \\
\end{array}$ & $\begin{array}{c}2 \text { daily } \\
\text { diaries (one } \\
\text { weekday, } \\
\text { one } \\
\text { weekend } \\
\text { day within } \\
\text { two weeks) } \\
\end{array}$ & $\begin{array}{l}1 \text { weekly } \\
\text { diary }\end{array}$ & $\begin{array}{l}2 \text { daily } \\
\text { diaries }\end{array}$ & $\begin{array}{l}1 \text { daily } \\
\text { diary }\end{array}$ & $\begin{array}{l}1 \text { daily } \\
\text { diary }\end{array}$ \\
\hline Time slot & $5 \mathrm{~min}$ & $10 \min$ & $\begin{array}{c}\text { No } \\
\text { minimum }\end{array}$ & $10 \min$ & $15 \min$ & $15 \min$ & $10 \min$ & $10 \min$ & $15 \min$ & $10 \mathrm{~min}$ & Free & Free \\
\hline $\begin{array}{l}\text { Respondent } \\
\mathrm{s}\end{array}$ & $\begin{array}{c}\text { Max } 2 \\
\text { household } \\
\text { members } \\
\text { aged 15+ }\end{array}$ & $\begin{array}{c}\text { Max } 2 \\
\text { household } \\
\text { members } \\
\text { aged 11+ }\end{array}$ & $\begin{array}{c}\text { All } \\
\text { household } \\
\text { members } \\
\text { aged 3+ }\end{array}$ & $\begin{array}{c}\text { All } \\
\text { household } \\
\text { members } \\
\text { aged 3+ }\end{array}$ & $\begin{array}{c}\text { All } \\
\text { household } \\
\text { members } \\
\text { aged 12+ }\end{array}$ & $\begin{array}{c}\text { All } \\
\text { household } \\
\text { members } \\
\text { aged 12+ }\end{array}$ & $\begin{array}{l}1 \text { household } \\
\text { member }+ \\
\text { spouse in a } \\
\text { smaller } \\
\text { household } \\
\text { aged 20-64 }\end{array}$ & $\begin{array}{l}1 \text { household } \\
\text { member }+ \\
\text { spouse in a } \\
\text { smaller } \\
\text { household } \\
\text { aged } 15-84\end{array}$ & $\begin{array}{c}\text { All } \\
\text { household } \\
\text { members } \\
\text { aged 14+ }\end{array}$ & $\begin{array}{l}\text { All } \\
\text { household } \\
\text { members } \\
\text { aged 14+ }\end{array}$ & $\begin{array}{c}\text { All } \\
\text { household } \\
\text { members } \\
\text { aged 12+ }\end{array}$ & $\begin{array}{c}1 \text { household } \\
\text { member } \\
\text { aged } 15+\end{array}$ \\
\hline $\begin{array}{l}\text { Number of } \\
\text { respondents }\end{array}$ & 16,078 & 18,380 & 38,110 & 44,606 & 3,263 & 2,204 & 3,636 & 2,998 & & 8,272 & 5,358 & 12,943 \\
\hline $\begin{array}{l}\text { Completed } \\
\text { diaries }\end{array}$ & 16,062 & 27,903 & 38,110 & 40,944 & 22,751 & 15,257 & 7,787 & 6,477 & 9,366 & 16,533 & 5,358 & 12,943 \\
\hline $\begin{array}{l}\text { Response } \\
\text { rate }\end{array}$ & $65 \%$ & $57 \%$ & n.a. & $91 \%$ & $54 \%$ & $37 \%$ & $75 \%$ & $41 \%$ & $51 \%$ & $65 \%-78 \%$ & $55 \%$ & $55 \%$ \\
\hline
\end{tabular}


TABLE 4 Sample sizes.

\begin{tabular}{lccccc}
\hline & & \multicolumn{2}{c}{ All, aged 20-60 } & \multicolumn{2}{c}{$\begin{array}{c}\text { Aged 20-60 with children } \\
(<\mathbf{1 8})\end{array}$} \\
& Year & Men & Women & Men & Women \\
\hline France & $1985 / 86$ & 5,451 & 6,251 & 3,038 & 3,529 \\
& $2009 / 10$ & 4,957 & 5,712 & 2,359 & 2,817 \\
Italy & $1988 / 89$ & 9,974 & 10,810 & 5,239 & 5,528 \\
& $2008 / 09$ & 10,417 & 10,897 & 3,806 & 4,284 \\
Netherlands & 1985 & 1,015 & 1,337 & 499 & 799 \\
\multirow{2}{*}{ Sweden } & 2005 & 624 & 797 & 289 & 344 \\
& $1990 / 91$ & 3,354 & 3,925 & 1,466 & 2,344 \\
\multirow{2}{*}{ UK } & $2010 / 11$ & 1,901 & 2,549 & 873 & 1,365 \\
& $1983 / 84$ & 2,431 & 3,746 & 1,359 & 2,211 \\
\multirow{2}{*}{ USA } & $2014 / 15$ & 4,390 & 5,218 & 1,686 & 2,349 \\
& 1985 & 1,173 & 1,402 & 530 & 650 \\
& 2006 & 3,476 & 4,564 & 2,066 & 2,986 \\
\hline
\end{tabular}


TABLE 5 Trends in (weighted) average daily housework time by gender (minutes per day).

\begin{tabular}{|c|c|c|c|c|c|c|c|c|}
\hline & \multicolumn{4}{|c|}{ Average time } & \multicolumn{2}{|c|}{$\begin{array}{l}\text { Participation rate } \\
\qquad(\%)\end{array}$} & \multicolumn{2}{|c|}{$\begin{array}{l}\text { Average time for } \\
\text { participants }\end{array}$} \\
\hline & Men & Women & Difference & $\begin{array}{l}\text { Women's } \\
\text { share }\end{array}$ & Men & Women & Men & Women \\
\hline \multicolumn{9}{|l|}{ France } \\
\hline 1985/86 & 117 & 260 & 143 & $69 \%$ & 89 & 99 & 132 & 261 \\
\hline $2009 / 10$ & 112 & $189 * * *$ & 77 & $63 \%$ & 75 & 93 & $149 * * *$ & $203 * * *$ \\
\hline \multicolumn{9}{|l|}{ Italy } \\
\hline 1988/89 & 57 & 318 & 261 & $85 \%$ & 60 & 96 & 95 & 330 \\
\hline 2008/09 & $83 * * *$ & $277 * * *$ & 194 & $69 \%$ & 63 & 95 & $131 * * *$ & $293 * * *$ \\
\hline \multicolumn{9}{|c|}{ Netherlands } \\
\hline 1985 & 128 & 306 & 178 & $71 \%$ & 98 & 100 & 131 & 306 \\
\hline 2005 & $114 * * *$ & $216 * * *$ & 102 & $62 \%$ & 98 & 100 & $116^{* *}$ & $216 * * *$ \\
\hline \multicolumn{9}{|l|}{ Sweden } \\
\hline 1990/91 & 140 & 220 & 80 & $61 \%$ & 91 & 98 & 153 & 224 \\
\hline 2010/11 & 142 & $175^{* * * *}$ & 33 & $55 \%$ & 91 & 97 & 156 & $181 * * *$ \\
\hline \multicolumn{9}{|l|}{ UK } \\
\hline 1983 & 91 & 248 & 157 & $73 \%$ & 79 & 96 & 114 & 258 \\
\hline 2015 & $107 * * *$ & $180 * * *$ & 73 & $64 \%$ & 85 & 96 & $125 * * *$ & $188 * * *$ \\
\hline \multicolumn{9}{|l|}{ USA } \\
\hline 1985 & 102 & 202 & 100 & $66 \%$ & 81 & 96 & 126 & 210 \\
\hline 2006 & $93 * *$ & $169 * * *$ & 76 & $67 \%$ & 76 & 93 & 122 & $182 * * *$ \\
\hline
\end{tabular}


TABLE 6 Trends in (weighted) average daily childcare time by gender (minutes per day).

\begin{tabular}{|c|c|c|c|c|c|c|c|c|}
\hline & \multicolumn{4}{|c|}{ Average time } & \multicolumn{2}{|c|}{$\begin{array}{l}\text { Participation rate } \\
\qquad(\%)\end{array}$} & \multicolumn{2}{|c|}{$\begin{array}{l}\text { Average time for } \\
\text { participants }\end{array}$} \\
\hline & Men & Women & Difference & $\begin{array}{l}\text { Women's } \\
\text { share }\end{array}$ & Men & Women & Men & Women \\
\hline \multicolumn{9}{|l|}{ France } \\
\hline 1985-86 & 22 & 82 & 60 & $79 \%$ & 45 & 76 & 49 & 81 \\
\hline 2009-10 & $41 * * *$ & $95 * * *$ & 54 & $70 \%$ & 51 & 74 & $107 * * *$ & $128 * * *$ \\
\hline \multicolumn{9}{|l|}{ Italy } \\
\hline 1988 & 19 & 57 & 38 & $75 \%$ & 27 & 61 & 68 & 92 \\
\hline 2008 & $44 * * *$ & $107 * * *$ & 63 & $71 \%$ & 52 & 77 & $84 * *$ & $138 * * *$ \\
\hline \multicolumn{9}{|c|}{ Netherlands } \\
\hline 1985 & 27 & 75 & 48 & $74 \%$ & 64 & 80 & 42 & 93 \\
\hline 2005 & $45 * * *$ & $110 * * *$ & 65 & $71 \%$ & 77 & 90 & $58 * * *$ & $122 * * *$ \\
\hline \multicolumn{9}{|l|}{ Sweden } \\
\hline 1990/91 & 52 & 88 & 36 & $63 \%$ & 58 & 74 & 88 & 121 \\
\hline 2010/11 & $71 * * *$ & 93 & 22 & $57 \%$ & 67 & 75 & $107 * *$ & 120 \\
\hline \multicolumn{9}{|l|}{ UK } \\
\hline 1983 & 31 & 95 & 64 & $75 \%$ & 42 & 73 & 73 & 129 \\
\hline 2015 & $59 * * *$ & $113 * * *$ & 54 & $66 \%$ & 57 & 78 & $103 * *$ & $146 * * *$ \\
\hline \multicolumn{9}{|l|}{ USA } \\
\hline 1985 & 22 & 71 & 49 & $76 \%$ & 36 & 68 & 63 & 105 \\
\hline 2010 & $56 * * *$ & $113 * * *$ & 57 & $67 \%$ & 53 & 75 & $105 * * *$ & $152 * * *$ \\
\hline
\end{tabular}

Note: Asterisks indicate significant change compared to previous survey year at ${ }^{* * *} \mathrm{p}<0.01,{ }^{* *} \mathrm{p}<0.05,{ }^{*} \mathrm{p}<0.1$ 
TABLE 7 Decomposition of 2000s-1980s change in average daily housework time for women in France, Italy, the Netherlands, Sweden, the UK, and USA.

\begin{tabular}{|c|c|c|c|c|c|c|c|c|c|}
\hline Housework & $\begin{array}{l}\text { France } \\
\text { overall }\end{array}$ & explained & unexplained & $\begin{array}{c}\text { Italy } \\
\text { overall }\end{array}$ & explained & unexplained & $\begin{array}{c}\text { Netherlands } \\
\text { overall }\end{array}$ & explained & unexplained \\
\hline Average time & $188.80^{* * *}$ & & & $276.75 * * *$ & & & $216.07 * * *$ & & \\
\hline $2000 s$ & (3.05) & & & (2.22) & & & (3.97) & & \\
\hline Average time & $259.82 * * *$ & & & $318.26 * * *$ & & & $305.98 * * *$ & & \\
\hline $1980 \mathrm{~s} / 1990 \mathrm{~s}$ & (2.30) & & & (2.21) & & & $(4.14)$ & & \\
\hline Raw difference & $-71.03 * * *$ & & & $-41.51 * * *$ & & & $-89.91 * * *$ & & \\
\hline & (3.82) & & & (3.13) & & & (5.74) & & \\
\hline Explained & $\begin{array}{c}-16.35^{* * * *} \\
(2.97)\end{array}$ & & & $\begin{array}{c}-18.10 * * * \\
(2.41)\end{array}$ & & & $\begin{array}{c}-41.67 * * * \\
(5.22)\end{array}$ & & \\
\hline Unexplained & $\begin{array}{c}-54.67 * * * \\
(3.85)\end{array}$ & & & $\begin{array}{c}-23.41 * * * \\
(2.77)\end{array}$ & & & $\begin{array}{c}-48.25^{* * * *} \\
(5.36)\end{array}$ & & \\
\hline $\begin{array}{l}\text { Employment } \\
\text { status }\end{array}$ & & $\begin{array}{c}-8.32 * * * \\
(1.99)\end{array}$ & $\begin{array}{l}-3.53 \\
(3.61)\end{array}$ & & $\begin{array}{c}-20.55^{* * * *} \\
(1.29)\end{array}$ & $\begin{array}{c}7.36 * * * \\
(2.23)\end{array}$ & & $\begin{array}{c}-29.85 * * * \\
(3.38)\end{array}$ & $\begin{array}{c}-27.18 * * * \\
(9.35)\end{array}$ \\
\hline Education & & $\begin{array}{c}-5.65 * * * \\
(1.16)\end{array}$ & $\begin{array}{c}9.64 \\
(6.02)\end{array}$ & & $\begin{array}{c}-7.50 * * * \\
(0.95)\end{array}$ & $\begin{array}{l}-0.79 \\
(3.36)\end{array}$ & & $\begin{array}{c}-6.87 * * * \\
(1.70)\end{array}$ & $\begin{array}{c}-24.15^{* *} \\
(10.84)\end{array}$ \\
\hline Partnership status & & & & & & & & & \\
\hline (Single) & & $\begin{array}{c}-6.18 * * * \\
(1.24)\end{array}$ & $\begin{array}{l}7.17^{*} \\
(3.93)\end{array}$ & & $\begin{array}{c}5.62 * * * \\
(0.99)\end{array}$ & $\begin{array}{c}11.81 * * * \\
(1.64)\end{array}$ & & $\begin{array}{c}-2.68^{* *} \\
(1.11)\end{array}$ & $\begin{array}{c}10.70 * * \\
(4.44)\end{array}$ \\
\hline Children & & $\begin{array}{c}-1.71 * * * \\
(0.48)\end{array}$ & $\begin{array}{c}5.98 \\
(5.54)\end{array}$ & & $\begin{array}{c}-5.90 * * * \\
(0.74)\end{array}$ & $\begin{array}{l}-7.75 \\
(5.30)\end{array}$ & & $\begin{array}{c}-9.92 * * * \\
(2.77)\end{array}$ & $\begin{array}{c}6.35 \\
(10.69)\end{array}$ \\
\hline Pre-schooler & & $\begin{array}{l}-0.07 \\
(0.10)\end{array}$ & $\begin{array}{c}0.36 \\
(2.52)\end{array}$ & & $\begin{array}{c}0.18 \\
(0.27)\end{array}$ & $\begin{array}{l}-0.83 \\
(1.25)\end{array}$ & & $\begin{array}{c}0.44 \\
(0.37)\end{array}$ & $\begin{array}{c}2.36 \\
(2.33)\end{array}$ \\
\hline Age & & $\begin{array}{c}6.89 * * * \\
(1.02)\end{array}$ & $\begin{array}{c}2.60 \\
(7.22)\end{array}$ & & $\begin{array}{c}9.75 * * * \\
(0.87)\end{array}$ & $\begin{array}{c}39.94 * * * \\
(5.81)\end{array}$ & & $\begin{array}{c}7.21 * * * \\
(1.73)\end{array}$ & $\begin{array}{l}-1.99 \\
(9.33)\end{array}$ \\
\hline Weekend & & $\begin{array}{c}-1.32 * * * \\
(0.36)\end{array}$ & $\begin{array}{l}1.65 \\
(1.61)\end{array}$ & & $\begin{array}{l}0.31 * \\
(0.17)\end{array}$ & $\begin{array}{c}9.23 * * * \\
(1.05)\end{array}$ & & & \\
\hline Constant & & & $\begin{array}{c}-78.56^{* * * *} \\
(13.47)\end{array}$ & & & $\begin{array}{c}-82.37 * * * \\
(10.22)\end{array}$ & & & $\begin{array}{l}-14.34 \\
(21.51)\end{array}$ \\
\hline Observations & 11,963 & & & 21,707 & & & 2,134 & & \\
\hline
\end{tabular}


TABLE 7 continued.

\begin{tabular}{|c|c|c|c|c|c|c|c|c|c|}
\hline Housework & $\begin{array}{c}\text { Sweden } \\
\text { overall }\end{array}$ & explained & unexplained & $\begin{array}{c}\text { UK } \\
\text { overall }\end{array}$ & explained & unexplained & $\begin{array}{c}\text { USA } \\
\text { overall }\end{array}$ & explained & unexplained \\
\hline Average time & $175.25 * * *$ & & & $179.59 * * *$ & & & $169.01 * * *$ & & \\
\hline $2000 s$ & $(2.70)$ & & & (1.96) & & & (2.95) & & \\
\hline Average time & $220.18 * * *$ & & & $247.75 * * *$ & & & $201.68 * * *$ & & \\
\hline $1980 \mathrm{~s} / 1990 \mathrm{~s}$ & (2.33) & & & (2.74) & & & (3.94) & & \\
\hline \multirow[t]{2}{*}{ Raw difference } & $-44.92 * * *$ & & & $-68.17 * * *$ & & & $-32.67 * * *$ & & \\
\hline & (3.56) & & & (3.37) & & & (4.92) & & \\
\hline \multirow[t]{2}{*}{ Explained } & 2.11 & & & $-38.08 * * *$ & & & $7.42 * *$ & & \\
\hline & $(2.24)$ & & & $(4.10)$ & & & $(3.51)$ & & \\
\hline \multirow[t]{2}{*}{ Unexplained } & $-47.03 * * *$ & & & $-30.09 * * *$ & & & $-40.10 * * *$ & & \\
\hline & $(3.71)$ & & & $(4.18)$ & & & $(5.43)$ & & \\
\hline \multirow{4}{*}{$\begin{array}{l}\text { Employment } \\
\text { status } \\
\text { Education }\end{array}$} & & 0.72 & -1.60 & & $-26.36 * * *$ & $-44.68 * * *$ & & -1.01 & 6.34 \\
\hline & & $(0.61)$ & $(4.08)$ & & (2.19) & $(3.85)$ & & $(2.25)$ & $(4.71)$ \\
\hline & & $-2.43 *$ & $5.14^{*}$ & & $-5.53 * * *$ & $9.02 * *$ & & $-2.60 *$ & -12.71 \\
\hline & & $(1.47)$ & $(3.08)$ & & (1.39) & $(3.68)$ & & $(1.56)$ & (13.57) \\
\hline \multirow{2}{*}{$\begin{array}{l}\text { Partnership status } \\
\text { (Single) }\end{array}$} & & $3.77 * * *$ & 132 & & & & & $3.44 * * *$ & 3.02 \\
\hline & & & & & $-7.79 * * *$ & $11.96 * * *$ & & & \\
\hline \multirow[t]{2}{*}{ Children } & & $\begin{array}{c}(0.76) \\
-2.61 * * *\end{array}$ & $\begin{array}{l}(2.60) \\
6.09 * *\end{array}$ & & $\begin{array}{c}(1.87) \\
-8.71 * * *\end{array}$ & $\begin{array}{c}(3.59) \\
13.26 * *\end{array}$ & & $\begin{array}{l}(0.88) \\
1.72 *\end{array}$ & $\begin{array}{c}(2.51) \\
4.07\end{array}$ \\
\hline & & $(0.87)$ & $(3.07)$ & & $(1.25)$ & $(6.08)$ & & $(1.04)$ & $\begin{array}{l}4.01 \\
(8.61)\end{array}$ \\
\hline \multirow[t]{2}{*}{ Pre-schooler } & & 0.34 & $5.71 * *$ & & $-0.81 * *$ & $3.77 *$ & & 1.34 & $-8.26 * * *$ \\
\hline & & $(0.38)$ & $(2.67)$ & & $(0.33)$ & $(2.16)$ & & $(1.02)$ & (3.17) \\
\hline \multirow[t]{2}{*}{ Age } & & $4.31 * * *$ & 0.32 & & $6.09 * * *$ & 1.95 & & $4.37 * * *$ & -8.96 \\
\hline & & $(0.78)$ & $(0.52)$ & & $(0.94)$ & $(5.38)$ & & $(1.20)$ & $(8.27)$ \\
\hline \multirow[t]{2}{*}{ Weekend } & & 0.12 & 4.97 & & $5.03 * *$ & $6.08 *$ & & 0.16 & 2.17 \\
\hline & & $(0.70)$ & $(3.37)$ & & $(2.18)$ & $(3.12)$ & & $(0.58)$ & $(3.03)$ \\
\hline \multirow{2}{*}{ Constant } & & & $-68.99 * * *$ & & & $-31.43 * * *$ & & & -25.77 \\
\hline & & & (9.18) & & & $(11.28)$ & & & (19.79) \\
\hline Observations & 6,474 & & & 8,964 & & & 5,966 & & \\
\hline
\end{tabular}


TABLE 8 Decomposition of 2000s-1980s change in average daily housework time for men in France, Italy, the Netherlands, Sweden, the UK, and USA.

\begin{tabular}{|c|c|c|c|c|c|c|c|c|c|}
\hline Housework & $\begin{array}{l}\text { France } \\
\text { overall }\end{array}$ & explained & unexplained & $\begin{array}{c}\text { Italy } \\
\text { overall }\end{array}$ & explained & unexplained & $\begin{array}{c}\text { Netherlands } \\
\text { overall }\end{array}$ & explained & unexplained \\
\hline Average time & $111.82 * * *$ & & & $82.77 * * *$ & & & $113.87 * * *$ & & \\
\hline $2000 s$ & $(2.98)$ & & & (1.38) & & & $(3.50)$ & & \\
\hline Average time & $117.17 * * *$ & & & $56.97 * * *$ & & & $128.50 * * *$ & & \\
\hline $1980 \mathrm{~s} / 1990 \mathrm{~s}$ & (2.01) & & & (1.09) & & & (4.11) & & \\
\hline \multirow[t]{2}{*}{ Raw difference } & -5.35 & & & $25.80 * * *$ & & & $-14.63 * * *$ & & \\
\hline & $(3.59)$ & & & $(1.76)$ & & & $(5.40)$ & & \\
\hline \multirow{2}{*}{ Explained } & -0.29 & & & $4.13 * * *$ & & & 1.73 & & \\
\hline & $(2.13)$ & & & $(0.90)$ & & & $(4.67)$ & & \\
\hline Unexplained & $\begin{array}{l}-5.06 \\
(3.79)\end{array}$ & & & $\begin{array}{c}21.67 * * * \\
(1.88)\end{array}$ & & & $\begin{array}{c}-16.35 * * * \\
(5.55)\end{array}$ & & \\
\hline \multirow[t]{2}{*}{ Employment status } & & $2.11 *$ & -2.10 & & $-0.82 * *$ & $5.04 * * *$ & & -1.12 & $-6.24 *$ \\
\hline & & $(1.27)$ & $(2.49)$ & & $(0.34)$ & $(0.97)$ & & $(3.40)$ & $(3.60)$ \\
\hline \multirow[t]{2}{*}{ Education } & & 0.12 & 4.94 & & 0.08 & 0.07 & & $-3.30 *$ & 2.65 \\
\hline & & $(0.93)$ & $(6.92)$ & & $(0.36)$ & (1.93) & & $(2.00)$ & $(10.26)$ \\
\hline \multicolumn{10}{|l|}{ Partnership status } \\
\hline \multirow{2}{*}{ (Single) } & & $-2.39 * * *$ & $10.78 * *$ & & $3.63 * * *$ & $3.18 * *$ & & -1.58 & 0.99 \\
\hline & & $(0.84)$ & $(4.29)$ & & $(0.52)$ & $(1.33)$ & & $(1.04)$ & $(4.75)$ \\
\hline \multirow[t]{2}{*}{ Children } & & $0.84 * *$ & 3.52 & & 0.18 & -6.37 & & $5.09 *$ & $-24.35^{*}$ \\
\hline & & $(0.37)$ & $(6.01)$ & & $(0.58)$ & $(4.07)$ & & $(2.67)$ & $(12.55)$ \\
\hline \multirow[t]{2}{*}{ Pre-schooler } & & 0.19 & -1.38 & & -0.20 & -0.84 & & -0.98 & $-5.34 * *$ \\
\hline & & $(0.15)$ & $(2.45)$ & & $(0.22)$ & $(0.80)$ & & $(0.67)$ & $(2.44)$ \\
\hline \multirow[t]{2}{*}{ Age } & & $3.17 * * *$ & $19.54 * * *$ & & $1.90 * * *$ & $16.67 * * *$ & & $3.62 * *$ & 9.10 \\
\hline & & $(0.75)$ & $(7.27)$ & & $(0.33)$ & (3.76) & & $(1.48)$ & (9.34) \\
\hline \multirow[t]{2}{*}{ Weekend } & & $-4.34 * * *$ & 0.37 & & $-0.64 * * *$ & $3.07 * * *$ & & & \\
\hline & & $(0.68)$ & (1.70) & & $(0.15)$ & $(0.75)$ & & & \\
\hline Constant & & & $-40.73 * * *$ & & & 0.85 & & & 6.84 \\
\hline & & & $(13.57)$ & & & $(6.50)$ & & & (19.42) \\
\hline Observations & 10,408 & & & 20,391 & & & 1,639 & & \\
\hline
\end{tabular}


TABLE 8 continued.

\begin{tabular}{|c|c|c|c|c|c|c|c|c|c|}
\hline Housework & $\begin{array}{c}\text { Sweden } \\
\text { overall }\end{array}$ & explained & unexplained & $\begin{array}{c}\text { UK } \\
\text { overall }\end{array}$ & explained & unexplained & $\begin{array}{c}\text { USA } \\
\text { overall }\end{array}$ & explained & unexplained \\
\hline Average time & $140.29 * * *$ & & & $106.80^{* * *}$ & & & $92.55 * * *$ & & \\
\hline $2000 s$ & $(2.23)$ & & & $(1.85)$ & & & $(2.43)$ & & \\
\hline Average time & $141.71 * * *$ & & & $90.89 * * *$ & & & $102.17 * * *$ & & \\
\hline $1980 \mathrm{~s} / 1990 \mathrm{~s}$ & (3.14) & & & $(2.42)$ & & & $(3.74)$ & & \\
\hline \multirow[t]{2}{*}{ Raw difference } & 1.42 & & & $15.92 * * *$ & & & $-9.62 * *$ & & \\
\hline & $(3.85)$ & & & $(3.05)$ & & & $(4.47)$ & & \\
\hline \multirow[t]{2}{*}{ Explained } & $5.96 * * *$ & & & $17.59 * * *$ & & & $7.50 * * *$ & & \\
\hline & $(1.85)$ & & & $(4.14)$ & & & $(2.75)$ & & \\
\hline Unexplained & $\begin{array}{l}-4.55 \\
(3.96)\end{array}$ & & & $\begin{array}{l}-1.67 \\
(4.44)\end{array}$ & & & $\begin{array}{l}-17.12 * * * \\
(5.05)\end{array}$ & & \\
\hline Employment status & & $\begin{array}{l}-0.33 \\
(0.49)\end{array}$ & $\begin{array}{c}30.97 \\
(15.91)\end{array}$ & & $\begin{array}{l}-0.12 \\
(1.73)\end{array}$ & $\begin{array}{c}-16.13^{* * *} \\
(2.20)\end{array}$ & & $\begin{array}{l}3.79 * * \\
(1.61)\end{array}$ & $\begin{array}{l}-2.95 \\
(2.74)\end{array}$ \\
\hline Education & & $\begin{array}{c}5.46^{* * * *} \\
(1.25)\end{array}$ & $\begin{array}{l}-1.94 \\
(1.89)\end{array}$ & & $\begin{array}{c}1.61 \\
(1.55)\end{array}$ & $\begin{array}{l}-3.76 \\
(3.70)\end{array}$ & & $\begin{array}{c}0.45 \\
(1.03)\end{array}$ & $\begin{array}{c}-2.32 \\
(13.53)\end{array}$ \\
\hline \multirow[t]{2}{*}{$\begin{array}{l}\text { Partnership status } \\
\text { (Single) }\end{array}$} & & $-0.54 * *$ & $-6.07 * *$ & & $-7.37 * * *$ & $8.21 * *$ & & $1.40 * *$ & 2.43 \\
\hline & & $(0.27)$ & $(2.62)$ & & $(2.28)$ & $(4.05)$ & & $(0.68)$ & $(2.79)$ \\
\hline \multirow[t]{2}{*}{ Children } & & -0.09 & -3.04 & & 1.32 & $12.93^{*}$ & & $2.10 *$ & -0.50 \\
\hline & & $(0.15)$ & $(4.68)$ & & $(1.22)$ & $(7.38)$ & & (1.09) & $(9.60)$ \\
\hline \multirow[t]{2}{*}{ Pre-schooler } & & -0.08 & 1.89 & & -0.01 & -0.66 & & $-1.73 * *$ & 3.91 \\
\hline & & $(0.11)$ & $(2.81)$ & & $(0.10)$ & $(1.94)$ & & $(0.83)$ & $(2.93)$ \\
\hline \multirow[t]{2}{*}{ Age } & & $1.63 * * *$ & -0.31 & & $0.62 *$ & $14.43 * * *$ & & 2.06 & 6.85 \\
\hline & & $(0.55)$ & $(0.3)$ & & $(0.33)$ & $(5.39)$ & & $(1.47)$ & $(8.51)$ \\
\hline \multirow[t]{2}{*}{ Weekend } & & -0.09 & $7.60 * *$ & & $21.53 * * *$ & $-8.30 * *$ & & -0.57 & $9.52 * * *$ \\
\hline & & $(1.01)$ & $(3.64)$ & & $(2.36)$ & $(3.24)$ & & $(0.62)$ & $(2.78)$ \\
\hline Constant & & & -18.45 & & & -8.39 & & & $-34.05^{*}$ \\
\hline Observations & 5,255 & & (18.24) & 6,819 & & (11.27) & 4.649 & & (19.78) \\
\hline
\end{tabular}


TABLE 9 Decomposition of 2000s-1980s change in average daily childcare time for women in France, Italy, the Netherlands, Sweden, the UK, and USA.

\begin{tabular}{|c|c|c|c|c|c|c|c|c|c|}
\hline Childcare & $\begin{array}{l}\text { France } \\
\text { overall }\end{array}$ & explained & unexplained & $\begin{array}{c}\text { Italy } \\
\text { overall }\end{array}$ & explained & unexplained & $\begin{array}{c}\text { Netherlands } \\
\text { overall }\end{array}$ & explained & unexplained \\
\hline Average time & $94.85 * * *$ & & & $106.58 * * *$ & & & $109.64 * * *$ & & \\
\hline $1980 \mathrm{~s} / 1990 \mathrm{~s}$ & $(2.99)$ & & & $(2.23)$ & & & (4.80) & & \\
\hline Average time & $81.80 * * *$ & & & $56.68 * * *$ & & & $74.85 * * *$ & & \\
\hline $2000 s$ & (1.69) & & & $(1.36)$ & & & $(3.10)$ & & \\
\hline \multirow{2}{*}{ Raw difference } & $13.05 * * *$ & & & $49.91 * * *$ & & & $34.79 * * *$ & & \\
\hline & $(3.44)$ & & & $(2.61)$ & & & $(5.71)$ & & \\
\hline \multirow[t]{2}{*}{ Explained } & -1.35 & & & $-2.59 *$ & & & $-9.08 *$ & & \\
\hline & $(2.75)$ & & & $(1.57)$ & & & $(5.17)$ & & \\
\hline \multirow[t]{2}{*}{ Unexplained } & $14.40 * * *$ & & & $52.49 * * *$ & & & $43.86 * * *$ & & \\
\hline & $(3.45)$ & & & $(2.49)$ & & & $(4.81)$ & & \\
\hline \multirow[t]{2}{*}{ Employment status } & & $-6.51 * * *$ & $12.20 * * *$ & & $-2.96 * * *$ & $4.92 * * *$ & & $-8.16^{* * *}$ & -6.11 \\
\hline & & (1.02) & (3.09) & & $(0.48)$ & $(1.86)$ & & $(1.88)$ & $(7.71)$ \\
\hline \multirow[t]{2}{*}{ Education } & & $8.62 * * *$ & -3.10 & & $5.58 * * *$ & 0.77 & & $3.68 * * *$ & -12.08 \\
\hline & & $(1.10)$ & $(5.77)$ & & $(0.77)$ & $(2.87)$ & & $(1.19)$ & $(10.70)$ \\
\hline Partnership status & & 0.44 & 0.43 & & $1.39 * *$ & 0.76 & & $-4.20 * * *$ & 0.27 \\
\hline (Single) & & $(1.35)$ & $(2.74)$ & & $(0.66)$ & $(1.16)$ & & $(1.35)$ & $(2.94)$ \\
\hline \multirow[t]{2}{*}{ Children } & & -0.44 & -4.77 & & $-0.39 * *$ & $10.65^{* * *}$ & & -0.28 & $17.05 * * *$ \\
\hline & & $(0.28)$ & $(3.84)$ & & $(0.19)$ & $(2.17)$ & & $(0.90)$ & $(5.89)$ \\
\hline \multirow[t]{2}{*}{ Pre-schooler } & & $2.61 * *$ & -5.62 & & -0.83 & $13.11 * * *$ & & 2.63 & $-7.57 *$ \\
\hline & & $(1.29)$ & $(3.90)$ & & $(0.79)$ & (2.34) & & $(3.46)$ & $(4.27)$ \\
\hline \multirow[t]{2}{*}{ Age } & & $-6.59 * * *$ & 10.34 & & $-5.54 * * *$ & 6.68 & & $-2.74 * *$ & -18.80 \\
\hline & & $(0.93)$ & $(10.03)$ & & $(0.73)$ & $(9.58)$ & & $(1.17)$ & (13.16) \\
\hline \multirow[t]{2}{*}{ Weekend } & & $0.53 * *$ & $-4.61 * * *$ & & $0.17 * *$ & $-5.21 * * *$ & & & \\
\hline & & $(0.23)$ & (1.37) & & $(0.08)$ & $(0.89)$ & & & \\
\hline \multirow[t]{2}{*}{ Constant } & & & 9.53 & & & $20.82^{*}$ & & & $71.10 * * *$ \\
\hline & & & $(14.67)$ & & & $(11.02)$ & & & $(19.82)$ \\
\hline Observations & 6,346 & & 9,812 & & & 1,143 & & & \\
\hline
\end{tabular}


TABLE 9 continued.

\begin{tabular}{|c|c|c|c|c|c|c|c|c|c|}
\hline Childcare & $\begin{array}{c}\text { Sweden } \\
\text { overall }\end{array}$ & explained & unexplained & $\begin{array}{c}\text { UK } \\
\text { overall }\end{array}$ & explained & unexplained & $\begin{array}{c}\text { USA } \\
\text { overall }\end{array}$ & explained & unexplained \\
\hline Average time & $93.42 * * *$ & & & $113.33 * * *$ & & & $113.37 * * *$ & & \\
\hline $1980 \mathrm{~s} / 1990 \mathrm{~s}$ & $(3.21)$ & & & $(2.68)$ & & & $(2.84)$ & & \\
\hline Average time & $88.49 * * *$ & & & $95.13^{* * *}$ & & & $71.23 * * *$ & & \\
\hline $2000 s$ & $(2.25)$ & & & $(2.47)$ & & & $(3.68)$ & & \\
\hline \multirow{2}{*}{ Raw difference } & 4.93 & & & $18.20 * * *$ & & & $42.14 * * *$ & & \\
\hline & $(3.92)$ & & & $(3.65)$ & & & $(4.65)$ & & \\
\hline \multirow[t]{2}{*}{ Explained } & 2.03 & & & 2.23 & & & $9.17 * * *$ & & \\
\hline & $(3.07)$ & & & $(4.22)$ & & & $(3.28)$ & & \\
\hline \multirow[t]{2}{*}{ Unexplained } & 2.9 & & & $15.98 * * *$ & & & $32.98 * * *$ & & \\
\hline & $(3.28)$ & & & $(4.43)$ & & & $(4.51)$ & & \\
\hline \multirow{2}{*}{ Employment status } & & 0.37 & -0.10 & & $-9.15 * * *$ & $-12.25 * * *$ & & 0.88 & $11.73 * * *$ \\
\hline & & $(1.37)$ & $(3.78)$ & & (1.18) & (4.32) & & $(1.55)$ & $(4.40)$ \\
\hline \multirow[t]{2}{*}{ Education } & & $5.99 * *$ & 1.34 & & $9.58 * * *$ & $-6.67 *$ & & 0.89 & $25.07 * *$ \\
\hline & & $(1.14)$ & $(2.95)$ & & $(1.53)$ & $(3.91)$ & & $(1.31)$ & $(10.48)$ \\
\hline Partnership status & & 1.79 & 2.12 & & -2.39 & 1.36 & & 0.37 & 2.79 \\
\hline (Single) & & $(1.27)$ & $(1.61)$ & & $(2.12)$ & $(3.27)$ & & $(0.44)$ & $(1.89)$ \\
\hline \multirow[t]{2}{*}{ Children } & & $0.81 * *$ & -1.93 & & -0.16 & $10.04 * * *$ & & 0.73 & $16.04 * * *$ \\
\hline & & $(0.33)$ & $(1.99)$ & & $(0.58)$ & $(3.63)$ & & $(0.74)$ & $(5.47)$ \\
\hline \multirow{2}{*}{ Pre-schooler } & & 1.42 & -4.34 & & $19.62 * * *$ & $-16.50 * * *$ & & $8.87 * * *$ & -2.89 \\
\hline & & $(1.33)$ & $(3.69)$ & & $(2.05)$ & $(4.25)$ & & (1.99) & $(4.65)$ \\
\hline \multirow[t]{2}{*}{ Age } & & $-4.75 * * *$ & -2.69 & & $-4.33 * * *$ & $-21.67 * * *$ & & $-2.03 * * *$ & 6.01 \\
\hline & & $(0.90)$ & $(2.45)$ & & $(0.81)$ & (7.64) & & $(0.74)$ & $(9.98)$ \\
\hline \multirow[t]{2}{*}{ Weekend } & & -0.01 & -0.10 & & $-10.94 * * *$ & -0.91 & & -0.54 & $-5.16^{* *}$ \\
\hline & & $(0.09)$ & $(2.98)$ & & (1.61) & $(2.94)$ & & $(0.51)$ & $(2.27)$ \\
\hline \multirow[t]{2}{*}{ Constant } & & & 8.59 & & & $62.58 * * *$ & & & -20.60 \\
\hline & & & $(8.41)$ & & & $(12.16)$ & & & $(16.49)$ \\
\hline Observations & 6,346 & & & & & & & & \\
\hline
\end{tabular}


TABLE 10 Decomposition of 2000s-1980s change in average daily childcare time for men in France, Italy, the Netherlands, Sweden, the UK, and USA.

\begin{tabular}{|c|c|c|c|c|c|c|c|c|c|}
\hline Childcare & $\begin{array}{l}\text { France } \\
\text { overall }\end{array}$ & explained & unexplained & $\begin{array}{c}\text { Italy } \\
\text { overall }\end{array}$ & explained & unexplained & $\begin{array}{c}\text { Netherlands } \\
\text { overall }\end{array}$ & explained & unexplained \\
\hline Average time & $41.27 * * *$ & & & $43.96 * * *$ & & & $44.58 * * *$ & & \\
\hline $2000 s$ & $(2.04)$ & & & (1.33) & & & $(3.06)$ & & \\
\hline Average time & $21.76 * * *$ & & & $18.61 * * *$ & & & $26.54 * * *$ & & \\
\hline 1980s/1990s & $(0.75)$ & & & $(0.76)$ & & & $(1.72)$ & & \\
\hline \multirow[t]{2}{*}{ Raw difference } & $19.51 * * *$ & & & $25.35 * * *$ & & & $18.04 * * *$ & & \\
\hline & $(2.17)$ & & & $(1.53)$ & & & $(3.51)$ & & \\
\hline \multirow[t]{2}{*}{ Explained } & $2.29 * *$ & & & 0.52 & & & 0.58 & & \\
\hline & $(1.17)$ & & & $(0.68)$ & & & $(2.85)$ & & \\
\hline \multirow[t]{2}{*}{ Unexplained } & $17.22 * * *$ & & & $24.83 * * *$ & & & $17.46^{* * *}$ & & \\
\hline & $(2.30)$ & & & $(1.55)$ & & & $(3.28)$ & & \\
\hline \multirow[t]{2}{*}{ Employment status } & & $1.31 * *$ & 1.50 & & $-0.43 * * *$ & $0.69 * *$ & & 1.74 & -0.02 \\
\hline & & $(0.58)$ & $(1.35)$ & & $(0.15)$ & $(0.33)$ & & $(1.73)$ & $(1.86)$ \\
\hline \multirow{2}{*}{ Education } & & $2.31 * * *$ & 0.72 & & $1.90 * * *$ & 0.02 & & $3.51 * * *$ & -4.60 \\
\hline & & $(0.44)$ & $(3.61)$ & & $(0.31)$ & $(1.60)$ & & $(0.81)$ & $(5.49)$ \\
\hline \multicolumn{10}{|l|}{ Partnership status } \\
\hline \multirow[t]{2}{*}{ (Single) } & & -0.25 & $3.90 * *$ & & 0.48 & 0.22 & & -1.07 & -1.72 \\
\hline & & $(0.74)$ & $(1.77)$ & & $(0.32)$ & $(0.55)$ & & $(0.96)$ & $(1.86)$ \\
\hline \multirow[t]{2}{*}{ Children } & & 0.11 & 1.81 & & 0.16 & $4.83 * * *$ & & -0.46 & 4.52 \\
\hline & & $(0.11)$ & $(3.22)$ & & $(0.12)$ & $(1.49)$ & & $(0.51)$ & $(3.95)$ \\
\hline \multirow[t]{2}{*}{ Pre-schooler } & & $0.62 *$ & $6.50 * * *$ & & -0.13 & $7.80 * * *$ & & -1.77 & 4.70 \\
\hline & & $(0.34)$ & $(2.31)$ & & $(0.27)$ & $(1.55)$ & & $(1.26)$ & (2.99) \\
\hline \multirow[t]{2}{*}{ Age } & & $-1.28 * * *$ & -11.39 & & $-1.37 * * *$ & 10.05 & & $-1.36^{*}$ & $14.65^{*}$ \\
\hline & & $(0.35)$ & (11.81) & & $(0.37)$ & $(11.51)$ & & $(0.81)$ & (7.69) \\
\hline \multirow[t]{2}{*}{ Weekend } & & $-0.52 * * *$ & -0.73 & & $-0.08 * *$ & $1.76 * * *$ & & & \\
\hline & & $(0.17)$ & (1.14) & & $(0.04)$ & $(0.63)$ & & & \\
\hline \multirow[t]{2}{*}{ Constant } & & & 14.92 & & & -0.54 & & & -0.07 \\
\hline & & & $(12.73)$ & & & (11.73) & & & $(11.45)$ \\
\hline Observations & 5,397 & & & 9,045 & & & 788 & & \\
\hline
\end{tabular}


TABLE 10 continued.

\begin{tabular}{|c|c|c|c|c|c|c|c|c|c|}
\hline Childcare & $\begin{array}{c}\text { Sweden } \\
\text { overall }\end{array}$ & explained & unexplained & $\begin{array}{c}\text { UK } \\
\text { overall }\end{array}$ & explained & unexplained & $\begin{array}{c}\text { USA } \\
\text { overall }\end{array}$ & explained & unexplained \\
\hline Average time & $71.27 * * *$ & & & $58.58 * * *$ & & & $56.02 * * *$ & & \\
\hline $2000 s$ & $(3.35)$ & & & (2.37) & & & (2.14) & & \\
\hline Average time & $51.50 * * *$ & & & $30.66 * * *$ & & & $22.49 * * *$ & & \\
\hline $1980 \mathrm{~s} / 1990 \mathrm{~s}$ & $(2.01)$ & & & (1.64) & & & $(2.25)$ & & \\
\hline \multirow{2}{*}{ Raw difference } & $19.77 * * *$ & & & $27.93 * * *$ & & & $33.52 * * *$ & & \\
\hline & (3.91) & & & $(2.88)$ & & & $(3.10)$ & & \\
\hline \multirow[t]{2}{*}{ Explained } & 0.57 & & & $6.39^{*}$ & & & $5.82 * * *$ & & \\
\hline & $(2.14)$ & & & $(3.34)$ & & & $(1.88)$ & & \\
\hline \multirow[t]{2}{*}{ Unexplained } & $19.20 * * *$ & & & $21.54 * * *$ & & & $27.71 * * *$ & & \\
\hline & $(3.84)$ & & & (4.34) & & & $(3.88)$ & & \\
\hline \multirow[t]{2}{*}{ Employment status } & & 0.91 & $-41.52 * * *$ & & -0.81 & 0.52 & & 1.01 & $3.01 *$ \\
\hline & & $(0.80)$ & (14.81) & & $(0.72)$ & $(1.58)$ & & $(0.72)$ & $(1.65)$ \\
\hline \multirow[t]{2}{*}{ Education } & & $2.52 * *$ & $-3.86 * *$ & & $2.56^{* *}$ & 4.75 & & 0.30 & $23.55 * * *$ \\
\hline & & $(1.10)$ & (1.96) & & $(1.20)$ & $(3.27)$ & & $(0.68)$ & $(8.89)$ \\
\hline \multirow{2}{*}{$\begin{array}{l}\text { Partnership status } \\
\text { (Single) }\end{array}$} & & 0.25 & -1.26 & & & & & & \\
\hline & & $(0.30)$ & $(0.94)$ & & $\begin{array}{l}-1.67 \\
(1.91)\end{array}$ & $\begin{array}{c}0.77 \\
(2.74)\end{array}$ & & $\begin{array}{c}0.22 \\
(0.27)\end{array}$ & $\begin{array}{c}0.11 \\
(0.77)\end{array}$ \\
\hline \multirow[t]{2}{*}{ Children } & & -0.22 & $-3.58 * *$ & & -0.41 & $5.73 *$ & & 0.16 & 3.67 \\
\hline & & $(0.37)$ & $(1.71)$ & & $(0.64)$ & $(3.46)$ & & $(0.52)$ & $(4.07)$ \\
\hline \multirow[t]{2}{*}{ Pre-schooler } & & -1.41 & 3.09 & & $4.42 * * *$ & $11.25 * * *$ & & $2.97 * * *$ & 4.20 \\
\hline & & (1.17) & (4.99) & & $(0.95)$ & $(3.86)$ & & (1.09) & $(4.12)$ \\
\hline \multirow[t]{2}{*}{ Age } & & $-1.52 * *$ & 4.27 & & $0.96 *$ & -4.90 & & 1.16 & -3.59 \\
\hline & & $(0.75)$ & (3.94) & & $(0.55)$ & $(8.13)$ & & $(0.96)$ & $(9.40)$ \\
\hline \multirow[t]{2}{*}{ Weekend } & & 0.05 & -1.43 & & 1.35 & $7.04 * *$ & & -0.00 & $3.20 *$ \\
\hline & & $(0.34)$ & $(3.45)$ & & $(1.52)$ & $(2.79)$ & & $(0.03)$ & $(1.90)$ \\
\hline \multirow[t]{2}{*}{ Constant } & & & $63.51 * * *$ & & & -3.61 & & & -6.44 \\
\hline & & & $(17.50)$ & & & (11.06) & & & $(14.45)$ \\
\hline Observations & & 2,339 & & & 3,043 & & & 2,596 & \\
\hline
\end{tabular}


TABLE A1 Time spent on specific housework and childcare activities.

\begin{tabular}{|c|c|c|c|c|c|c|c|c|c|c|c|c|}
\hline & \multicolumn{4}{|c|}{ France } & \multicolumn{4}{|c|}{ Italy } & \multicolumn{4}{|c|}{ Netherlands } \\
\hline & \multicolumn{2}{|c|}{ Men } & \multicolumn{2}{|c|}{ Women } & \multicolumn{2}{|c|}{ Men } & \multicolumn{2}{|c|}{ Women } & \multicolumn{2}{|c|}{ Men } & \multicolumn{2}{|c|}{ Women } \\
\hline & 1985 & 2009 & 1985 & 2009 & 1988 & 2008 & 1988 & 2008 & 1985 & 2005 & 1985 & 2005 \\
\hline \multicolumn{13}{|l|}{ Housework } \\
\hline Cooking & 25 & 24 & 104 & 68 & 12 & 18 & 154 & 101 & 27 & 28 & 96 & 65 \\
\hline Cleaning & 11 & 15 & 53 & 49 & 3 & 14 & 70 & 85 & 8 & 7 & 49 & 32 \\
\hline $\begin{array}{r}\text { Laundry and } \\
\text { ironing }\end{array}$ & 2 & 4 & 32 & 21 & 0 & 1 & 41 & 28 & 2 & 4 & 26 & 21 \\
\hline $\begin{array}{r}\text { Home repairs \& } \\
\text { gardening }\end{array}$ & 48 & 43 & 15 & 15 & 16 & 18 & 10 & 8 & 52 & 33 & 29 & 26 \\
\hline $\begin{array}{r}\text { Sewing, mending } \\
\text { and maintaining } \\
\text { textiles }\end{array}$ & 0 & 0 & 18 & 2 & & & & & 1 & 0 & 37 & 5 \\
\hline Shopping & 17 & 16 & 28 & 26 & 11 & 26 & 33 & 50 & 25 & 28 & 46 & 47 \\
\hline $\begin{array}{r}\text { Caregiving (to } \\
\text { other adults) }\end{array}$ & 0 & 1 & 1 & 1 & 3 & 3 & 7 & 3 & 10 & 7 & 15 & 11 \\
\hline $\begin{array}{r}\text { Household } \\
\text { administration }\end{array}$ & 13 & 10 & 9 & 7 & 12 & 3 & 3 & 3 & 3 & 5 & 5 & 6 \\
\hline Transportation & & & & & & & & & 1 & 3 & 2 & 3 \\
\hline $\begin{array}{r}\text { Total housework } \\
\text { Childcare }\end{array}$ & 117 & 111 & 260 & 189 & 57 & 82 & 318 & 277 & 129 & 115 & 305 & 216 \\
\hline Routine childcare & 9 & 19 & 56 & 54 & 5 & 11 & 37 & 49 & 11 & 17 & 42 & 48 \\
\hline $\begin{array}{r}\text { Interactive } \\
\text { childcare }\end{array}$ & 7 & 11 & 11 & 12 & 10 & 18 & 8 & 19 & 11 & 20 & 19 & 32 \\
\hline $\begin{array}{l}\text { Help with } \\
\text { homework }\end{array}$ & 2 & 3 & 7 & 8 & 2 & 3 & 9 & 12 & 1 & 2 & 2 & 4 \\
\hline Transports & 3 & 9 & 8 & 20 & 1 & 11 & 2 & 28 & 3 & 7 & 12 & 26 \\
\hline \multirow[t]{4}{*}{ Total childcare } & 21 & 42 & 82 & 94 & 19 & 43 & 57 & 108 & 26 & 46 & 75 & 110 \\
\hline & \multicolumn{4}{|c|}{ Sweden } & \multicolumn{4}{|c|}{ UK } & \multicolumn{4}{|c|}{ USA } \\
\hline & \multicolumn{2}{|c|}{ Men } & \multicolumn{2}{|c|}{ Women } & \multicolumn{2}{|c|}{ Men } & \multicolumn{2}{|c|}{ Women } & \multicolumn{2}{|c|}{ Men } & \multicolumn{2}{|c|}{ Women } \\
\hline & 1990 & 2010 & 1990 & 2010 & 1983 & 2015 & 1983 & 2015 & 1985 & 2006 & 1985 & 2006 \\
\hline \multicolumn{13}{|l|}{ Housework } \\
\hline Cooking & 36 & 38 & 82 & 59 & 29 & 23 & 96 & 48 & 18 & 15 & 74 & 38 \\
\hline Cleaning & 19 & 22 & 40 & 35 & 7 & 27 & 37 & 54 & 20 & 10 & 43 & 39 \\
\hline $\begin{array}{r}\text { Laundry and } \\
\text { ironing }\end{array}$ & 4 & 5 & 23 & 14 & 2 & 3 & 25 & 16 & 2 & 4 & 20 & 23 \\
\hline $\begin{array}{r}\text { Home repairs \& } \\
\text { gardening }\end{array}$ & 30 & 28 & 10 & 12 & 21 & 27 & 10 & 20 & 22 & 35 & 11 & 21 \\
\hline $\begin{array}{r}\text { Sewing, mending } \\
\text { and maintaining } \\
\text { textiles }\end{array}$ & 0 & 0 & 11 & 3 & 1 & 0 & 13 & 2 & & & & \\
\hline Shopping & 33 & 34 & 40 & 39 & 21 & 17 & 39 & 23 & 17 & 19 & 30 & 34 \\
\hline $\begin{array}{r}\text { Caregiving (to } \\
\text { other adults) }\end{array}$ & 13 & 9 & 9 & 7 & 1 & 3 & 3 & 3 & 5 & 0 & 4 & 1 \\
\hline $\begin{array}{r}\text { Household } \\
\text { administration }\end{array}$ & 6 & 6 & 5 & 7 & 8 & 4 & 26 & 5 & 19 & 10 & 20 & 13 \\
\hline Unspecified & & & & & & 2 & & 9 & & & & \\
\hline $\begin{array}{r}\text { Total housework } \\
\text { Childcare }\end{array}$ & 141 & 142 & 220 & 176 & 91 & 107 & 248 & 180 & 102 & 93 & 202 & 169 \\
\hline Routine childcare & 21 & 33 & 46 & 54 & 13 & 27 & 59 & 65 & 10 & 21 & 44 & 55 \\
\hline
\end{tabular}




$\begin{array}{rcccccccccccc}\begin{array}{r}\text { Interactive } \\ \text { childcare }\end{array} & 23 & 25 & 30 & 26 & 8 & 20 & 13 & 25 & 7 & 20 & 11 & 28 \\ \begin{array}{r}\text { Help with } \\ \text { homework }\end{array} & 1 & 2 & 2 & 2 & 1 & 1 & 2 & 3 & 1 & 4 & 4 & 9 \\ \begin{array}{r}\text { Transports } \\ \text { tal childcare }\end{array} & \mathbf{5 1} & 11 & 9 & 11 & 8 & 10 & 22 & 20 & 5 & 10 & 12 & 21 \\ \end{array}$


TABLE A2 Complete OLS regression output for daily housework, by gender, in France and

Italy.

\begin{tabular}{|c|c|c|c|c|c|c|c|c|}
\hline & \multicolumn{3}{|c|}{ France } & \multicolumn{5}{|c|}{ Italy } \\
\hline & Women & & Men & & Women & & Men & \\
\hline & 1985 & 2010 & 1985 & 2010 & 1988 & 2008 & 1988 & 2008 \\
\hline Employed & Ref. & Ref. & Ref. & Ref. & Ref. & Ref. & Ref. & Ref. \\
\hline Unemployed & $\begin{array}{c}125.31 * * * \\
(8.72)\end{array}$ & $\begin{array}{c}101.48 * * * \\
(10.63)\end{array}$ & $\begin{array}{c}94.77 * * * \\
(10.69)\end{array}$ & $\begin{array}{l}70.20 * * * \\
(14.74)\end{array}$ & $\begin{array}{c}111.97 * * * \\
(6.73)\end{array}$ & $\begin{array}{l}120.51 * * * \\
(8.57)\end{array}$ & $\begin{array}{c}33.71 * * * \\
(5.68)\end{array}$ & $\begin{array}{c}52.44 * * * \\
(8.89)\end{array}$ \\
\hline Studying & $\begin{array}{c}-53.17 * * * \\
(11.19)\end{array}$ & $\begin{array}{l}-18.49 \\
(17.03)\end{array}$ & $\begin{array}{c}-15.62 \\
(9.95)\end{array}$ & $\begin{array}{c}-3.96 \\
(12.43)\end{array}$ & $\begin{array}{c}7.70 \\
(7.98)\end{array}$ & $\begin{array}{l}-6.95 \\
(7.35)\end{array}$ & $\begin{array}{l}-0.08 \\
(4.18)\end{array}$ & $\begin{array}{c}0.26 \\
(4.47)\end{array}$ \\
\hline Housemaker & $\begin{array}{c}129.35 * * * \\
(4.92)\end{array}$ & $\begin{array}{c}115.22 * * * \\
(9.31)\end{array}$ & $\begin{array}{c}115.15^{* *} \\
(55.72)\end{array}$ & $\begin{array}{c}291.72 * * * \\
(100.56)\end{array}$ & $\begin{array}{c}141.25 * * * \\
(4.12)\end{array}$ & $\begin{array}{c}170.55 * * * \\
(4.53)\end{array}$ & & \\
\hline $\begin{array}{l}\text { Out of the labour } \\
\text { force }\end{array}$ & $\begin{array}{c}92.77 * * * \\
(13.39)\end{array}$ & $\begin{array}{l}72.91 * * * \\
(14.70)\end{array}$ & $\begin{array}{l}112.03 * * * \\
(12.97)\end{array}$ & $\begin{array}{c}83.76 * * * \\
(15.44)\end{array}$ & $\begin{array}{c}125.83 * * * \\
(8.61)\end{array}$ & $\begin{array}{l}117.32 * * * \\
(9.24)\end{array}$ & $\begin{array}{c}67.20 * * * \\
(6.78)\end{array}$ & $\begin{array}{c}129.57 * * * \\
(8.79)\end{array}$ \\
\hline Part time & $\begin{array}{l}31.28 * * * \\
(7.24)\end{array}$ & $\begin{array}{l}31.06 * * * \\
(7.13)\end{array}$ & $\begin{array}{c}-0.62 \\
(16.94)\end{array}$ & $\begin{array}{c}8.42 \\
(10.77)\end{array}$ & & & & \\
\hline Education, low & Ref. & Ref. & Ref. & Ref. & Ref. & Ref. & Ref. & Ref. \\
\hline $\begin{array}{l}\text { Secondary } \\
\text { education }\end{array}$ & $\begin{array}{c}-13.53 * * * \\
(4.34)\end{array}$ & $\begin{array}{l}-1.58 \\
(7.46)\end{array}$ & $\begin{array}{c}5.62 \\
(4.03)\end{array}$ & $\begin{array}{c}17.12 * * \\
(8.29)\end{array}$ & $\begin{array}{c}-23.02 * * * \\
(4.03)\end{array}$ & $\begin{array}{l}-23.10 * * * \\
(4.20)\end{array}$ & $\begin{array}{c}3.71 \\
(2.36)\end{array}$ & $\begin{array}{l}2.90 \\
(2.82)\end{array}$ \\
\hline $\begin{array}{l}\text { Higher } \\
\text { education }\end{array}$ & $\begin{array}{l}-27.17 * * * \\
(5.57)\end{array}$ & -12.34 & $\begin{array}{l}-1.30 \\
(5.82)\end{array}$ & -4.52 & $-48.07 * * *$ & $-53.00 * * *$ & $-5.99 *$ & -2.72 \\
\hline Married couple & Ref. & $\begin{array}{l}\text { Ref. } \\
\text { R.UJ) }\end{array}$ & $\begin{array}{l}\text { Ref. } \\
\text { Ref) }\end{array}$ & $\begin{array}{l}(0.52) \\
\text { Ref. }\end{array}$ & Ref. & Ref. & Ref. & Ref. \\
\hline Unmarried & $-33.58 * * *$ & $-13.88 * *$ & $-18.27 * * *$ & 10.84 & $-123.97 * * *$ & $-18.89 * *$ & $-21.62 * * *$ & $11.99 *$ \\
\hline Couple & (8.14) & $(6.88)$ & $(6.15)$ & $(7.86)$ & (6.18) & $(8.44)$ & $(3.86)$ & $(6.52)$ \\
\hline Single & $\begin{array}{c}-47.51 * * * \\
(6.10)\end{array}$ & $\begin{array}{c}-38.10 * * * \\
(6.90)\end{array}$ & $\begin{array}{l}-7.35 \\
(6.39)\end{array}$ & $\begin{array}{c}3.37 \\
(9.21)\end{array}$ & $\begin{array}{c}-79.21 * * * \\
(5.88)\end{array}$ & $\begin{array}{c}-42.05 * * * \\
(4.35)\end{array}$ & $\begin{array}{c}7.16 \\
(4.80)\end{array}$ & $\begin{array}{c}16.04 * * * \\
(3.61)\end{array}$ \\
\hline No children & $\begin{array}{c}-21.29 * * * \\
(5.39)\end{array}$ & $\begin{array}{l}-7.93 \\
(7.87)\end{array}$ & $\begin{array}{c}4.93 \\
(5.35)\end{array}$ & $\begin{array}{c}8.05 \\
(8.55)\end{array}$ & $\begin{array}{c}-29.90 * * * \\
(5.39)\end{array}$ & $\begin{array}{c}-38.90 * * * \\
(5.46)\end{array}$ & $\begin{array}{l}-2.48 \\
(3.72)\end{array}$ & $\begin{array}{c}-12.49 * * * \\
(4.37)\end{array}$ \\
\hline 1 child & Ref. & Ref. & Ref. & Ref. & Ref. & Ref. & Ref. & Ref. \\
\hline 2 children & $\begin{array}{c}6.37 \\
(5.17)\end{array}$ & $\begin{array}{l}10.15 \\
(7.66)\end{array}$ & $\begin{array}{l}-8.14 \\
(5.25)\end{array}$ & $\begin{array}{l}-4.48 \\
(8.10)\end{array}$ & $\begin{array}{c}28.47 * * * \\
(4.99)\end{array}$ & $\begin{array}{c}19.24 * * * \\
(5.74)\end{array}$ & $\begin{array}{l}-3.55 \\
(3.09)\end{array}$ & $\begin{array}{l}-5.61 \\
(4.22)\end{array}$ \\
\hline $\begin{array}{l}3 \text { or more } \\
\text { children }\end{array}$ & $\begin{array}{c}15.96 * * \\
(6.87)\end{array}$ & $\begin{array}{l}18.90 * * \\
(9.22)\end{array}$ & $\begin{array}{c}-19.79 * * * \\
(6.59)\end{array}$ & $\begin{array}{c}-8.97 \\
(10.48)\end{array}$ & $\begin{array}{l}42.51 * * * \\
(8.25)\end{array}$ & $\begin{array}{l}13.70 \\
(9.72)\end{array}$ & $\begin{array}{c}-10.32 * * \\
(4.48)\end{array}$ & $\begin{array}{l}-0.15 \\
(7.12)\end{array}$ \\
\hline Preschooler & $\begin{array}{l}-8.00 \\
(5.36)\end{array}$ & $\begin{array}{l}-6.60 \\
(7.98)\end{array}$ & $\begin{array}{l}9.63^{*} \\
(4.95)\end{array}$ & $\begin{array}{c}4.36 \\
(7.92)\end{array}$ & $\begin{array}{l}-3.50 \\
(5.24)\end{array}$ & $\begin{array}{l}-8.75 \\
(5.96)\end{array}$ & $\begin{array}{c}2.77 \\
(3.10)\end{array}$ & $\begin{array}{l}-2.71 \\
(4.21)\end{array}$ \\
\hline Age, $20-30$ years & Ref. & Ref. & Ref. & Ref. & Ref. & Ref. & Ref. & Ref. \\
\hline $30-39$ years & $\begin{array}{c}26.27 * * * \\
(4.93)\end{array}$ & $\begin{array}{c}36.72 * * * \\
(8.15)\end{array}$ & $\begin{array}{c}26.74 * * * \\
(4.97)\end{array}$ & $\begin{array}{c}44.24 * * * \\
(8.75)\end{array}$ & $\begin{array}{c}30.05 * * * \\
(5.08)\end{array}$ & $\begin{array}{c}66.54 * * * \\
(5.84)\end{array}$ & $\begin{array}{c}15.69 * * * \\
(3.18)\end{array}$ & $\begin{array}{c}23.19 * * * \\
(3.71)\end{array}$ \\
\hline 40-49 years & $\begin{array}{c}50.93 * * * \\
(6.31)\end{array}$ & $\begin{array}{c}56.29 * * * \\
(9.35)\end{array}$ & $\begin{array}{c}33.29 * * * \\
(6.40)\end{array}$ & $\begin{array}{c}56.41 * * * \\
(8.99)\end{array}$ & $\begin{array}{c}73.22 * * * \\
(5.81)\end{array}$ & $\begin{array}{c}116.40 * * * \\
(6.19)\end{array}$ & $\begin{array}{c}20.15^{* * * *} \\
(3.63)\end{array}$ & $\begin{array}{c}40.73 * * * \\
(4.25)\end{array}$ \\
\hline $50-60$ years & $\begin{array}{c}82.08 * * * \\
(6.50)\end{array}$ & $\begin{array}{c}75.65 * * * \\
(10.03)\end{array}$ & $\begin{array}{c}32.67 * * * \\
(6.24)\end{array}$ & $\begin{array}{c}65.90 * * * \\
(9.89)\end{array}$ & $\begin{array}{c}90.26 * * * \\
(6.31)\end{array}$ & $\begin{array}{c}155.32 * * * \\
(6.20)\end{array}$ & $\begin{array}{c}28.65 * * * \\
(4.18)\end{array}$ & $\begin{array}{c}60.59 * * * \\
(4.17)\end{array}$ \\
\hline Weekend & $\begin{array}{c}18.09 * * * \\
(4.20)\end{array}$ & $\begin{array}{c}25.93 * * * \\
(6.40)\end{array}$ & $\begin{array}{c}48.81 * * * \\
(4.56)\end{array}$ & $\begin{array}{c}50.61 * * * \\
(6.88)\end{array}$ & $\begin{array}{c}-30.23 * * * \\
(2.74)\end{array}$ & $\begin{array}{l}5.41 * \\
(2.93)\end{array}$ & $\begin{array}{c}24.58 * * * \\
(1.87)\end{array}$ & $\begin{array}{c}36.70 * * * \\
(2.30)\end{array}$ \\
\hline Constant & $\begin{array}{c}199.22 * * * \\
(6.34)\end{array}$ & $\begin{array}{c}120.65 * * * \\
(11.89)\end{array}$ & $\begin{array}{c}72.72 * * * \\
(6.07)\end{array}$ & $\begin{array}{c}32.00 * * * \\
(12.13)\end{array}$ & $\begin{array}{c}253.84 * * * \\
(6.62)\end{array}$ & $\begin{array}{c}171.47 * * * \\
(7.79)\end{array}$ & $\begin{array}{c}31.86^{* * * *} \\
(3.85)\end{array}$ & $\begin{array}{c}32.71 * * * \\
(5.24)\end{array}$ \\
\hline Observations & 6,251 & 5,712 & 5,451 & 4,957 & 10,810 & 10,897 & 9,974 & 10,417 \\
\hline R-squared & 0.32 & 0.19 & 0.13 & 0.09 & 0.46 & 0.40 & 0.09 & 0.16 \\
\hline
\end{tabular}


TABLE A3 Complete OLS regression output for daily housework, by gender, in the

Netherlands and Sweden.

\begin{tabular}{|c|c|c|c|c|c|c|c|c|}
\hline & \multicolumn{3}{|c|}{ Netherlands } & \multicolumn{5}{|c|}{ Sweden } \\
\hline & Women & & Men & & Women & & Men & \\
\hline & 1985 & 2005 & 1985 & 2005 & 1990 & 2010 & 1990 & 2010 \\
\hline Employed & Ref. & Ref. & Ref. & Ref. & Ref. & Ref. & Ref. & Ref. \\
\hline Unemployed & $\begin{array}{c}97.58 * * * \\
(17.85)\end{array}$ & $\begin{array}{c}58.83 * * * \\
(20.92)\end{array}$ & $\begin{array}{c}109.10 * * * \\
(16.82)\end{array}$ & $\begin{array}{c}79.73 * * * \\
(24.72)\end{array}$ & $\begin{array}{c}17.25 * * * \\
(5.31)\end{array}$ & $\begin{array}{l}-4.45 \\
(6.15)\end{array}$ & $\begin{array}{l}24.48^{*} \\
(13.23)\end{array}$ & $\begin{array}{c}-6.74 \\
(12.26)\end{array}$ \\
\hline Studying & $\begin{array}{l}-30.00^{*} \\
(16.01)\end{array}$ & $\begin{array}{c}-41.10 * * * \\
(13.91)\end{array}$ & $\begin{array}{c}6.01 \\
(10.51)\end{array}$ & $\begin{array}{c}-6.32 \\
(17.21)\end{array}$ & $\begin{array}{c}-3.86 \\
(10.06)\end{array}$ & $\begin{array}{c}0.80 \\
(10.87)\end{array}$ & $\begin{array}{l}-17.74 * \\
(9.81)\end{array}$ & $\begin{array}{l}-11.43 \\
(10.51)\end{array}$ \\
\hline Housemaker & $\begin{array}{c}127.10^{* * * *} \\
(10.73)\end{array}$ & $\begin{array}{c}87.79 * * * \\
(11.10)\end{array}$ & $\begin{array}{c}172.73 * * * \\
(9.52)\end{array}$ & $\begin{array}{c}20.02 \\
(12.16)\end{array}$ & $\begin{array}{c}31.97 * * * \\
(10.59)\end{array}$ & $\begin{array}{c}54.73 * * * \\
(10.59)\end{array}$ & $\begin{array}{c}12.84 * * * \\
(10.38)\end{array}$ & $\begin{array}{c}22.38 \\
(14.08)\end{array}$ \\
\hline $\begin{array}{l}\text { Out of the labour } \\
\text { force }\end{array}$ & $\begin{array}{c}69.90 * * * \\
(17.01)\end{array}$ & $\begin{array}{c}60.54 * * * \\
(14.39)\end{array}$ & $\begin{array}{c}113.17 * * * \\
(24.45)\end{array}$ & $\begin{array}{c}72.67 * * * \\
(17.66)\end{array}$ & $\begin{array}{c}68.61 * * * \\
(10.03)\end{array}$ & $\begin{array}{c}42.84 * * * \\
(14.78)\end{array}$ & $\begin{array}{c}148.22 * * \\
(64.52)\end{array}$ & $\begin{array}{c}5.19 \\
(41.21)\end{array}$ \\
\hline Part time & $\begin{array}{c}47.15^{* * * *} \\
(10.82)\end{array}$ & $\begin{array}{l}10.30 \\
(7.11)\end{array}$ & $\begin{array}{l}19.44 * \\
(11.78)\end{array}$ & $\begin{array}{c}15.77 \\
(11.25)\end{array}$ & & & & \\
\hline Education, low & Ref. & Ref. & Ref. & Ref. & Ref. & Ref. & Ref. & Ref. \\
\hline Secondary & $\begin{array}{c}-18.85^{* * *} \\
(6.86)\end{array}$ & $\begin{array}{c}-44.76^{* * *} \\
(11.21)\end{array}$ & $\begin{array}{l}-15.16^{*} \\
(8.67)\end{array}$ & $\begin{array}{l}-14.71 \\
(9.83)\end{array}$ & $\begin{array}{c}-8.9 \\
(5.78)\end{array}$ & $\begin{array}{c}7.19 \\
(11.98)\end{array}$ & $\begin{array}{c}14.27 * * * \\
(5.33)\end{array}$ & $\begin{array}{c}4.43 \\
(10.31)\end{array}$ \\
\hline Higher education & $\begin{array}{c}-38.12 * * * \\
(8.46)\end{array}$ & $\begin{array}{c}-70.28^{* * *} \\
(11.62)\end{array}$ & $\begin{array}{l}-13.09 \\
(9.36)\end{array}$ & $\begin{array}{l}-6.82 \\
(9.68)\end{array}$ & $\begin{array}{c}-16.74 * * * \\
(6.23)\end{array}$ & $\begin{array}{c}12.69 \\
(12.11)\end{array}$ & $\begin{array}{c}17.10^{* * * *} \\
(5.91)\end{array}$ & $\begin{array}{l}23.86 * * \\
(10.51)\end{array}$ \\
\hline Married couple & Ref. & Ref. & Ref. & Ref. & Ref. & Ref. & Ref. & Ref. \\
\hline $\begin{array}{l}\text { Unmarried } \\
\text { couple }\end{array}$ & $\begin{array}{c}-41.02 * * * \\
(12.68)\end{array}$ & $\begin{array}{l}-2.99 \\
(8.75)\end{array}$ & $\begin{array}{l}-21.36^{*} \\
(12.11)\end{array}$ & $\begin{array}{c}-23.93 * * * \\
(7.69)\end{array}$ & Ref. & Ref. & Ref. & Ref. \\
\hline Single & $\begin{array}{c}-24.36^{* * *} \\
(9.11)\end{array}$ & $\begin{array}{l}-10.68 \\
(9.50)\end{array}$ & $\begin{array}{c}-9.54 \\
(11.02)\end{array}$ & $\begin{array}{c}0.65 \\
(10.72)\end{array}$ & $\begin{array}{c}-21.17 * * * \\
(4.80)\end{array}$ & $\begin{array}{c}-17.58^{* * * *} \\
(5.97)\end{array}$ & $\begin{array}{l}-2.68 \\
(5.65)\end{array}$ & $\begin{array}{c}-23.93 * * * \\
(7.24)\end{array}$ \\
\hline No kids at home & $\begin{array}{c}-27.37 * * \\
(11.32)\end{array}$ & $\begin{array}{c}-24.76^{* *} \\
(9.94)\end{array}$ & $\begin{array}{c}15.68 \\
(13.85)\end{array}$ & $\begin{array}{c}-22.25^{* *} \\
(10.07)\end{array}$ & $\begin{array}{c}-17.33^{* * * *} \\
(6.52)\end{array}$ & $\begin{array}{l}-2.28 \\
(7.94)\end{array}$ & $\begin{array}{l}-1.97 \\
(7.32)\end{array}$ & $\begin{array}{c}-6.11 \\
(10.11)\end{array}$ \\
\hline 1 child & Ref. & Ref. & Ref. & Ref. & Ref. & Ref. & Ref. & Ref. \\
\hline 2 children & $\begin{array}{l}11.61 \\
(9.33)\end{array}$ & $\begin{array}{l}23.50 * * \\
(10.47)\end{array}$ & $\begin{array}{c}0.05 \\
(11.68)\end{array}$ & $\begin{array}{c}-25.68 * * \\
(9.95)\end{array}$ & $\begin{array}{c}9.26 \\
(6.55)\end{array}$ & $\begin{array}{c}3.80 \\
(7.74)\end{array}$ & $\begin{array}{l}-3.04 \\
(7.27)\end{array}$ & $\begin{array}{c}12.98 \\
(10.08)\end{array}$ \\
\hline $\begin{array}{l}3 \text { or more } \\
\text { children }\end{array}$ & $\begin{array}{c}10.38 \\
(11.52)\end{array}$ & $\begin{array}{c}43.46^{* * * *} \\
(13.85)\end{array}$ & $\begin{array}{l}-22.16^{*} \\
(12.88)\end{array}$ & $\begin{array}{c}-1.96 \\
(14.95)\end{array}$ & $\begin{array}{c}34.20 * * * \\
(9.64)\end{array}$ & $\begin{array}{c}17.27 \\
(11.31)\end{array}$ & $\begin{array}{c}9.79 \\
(9.99)\end{array}$ & $\begin{array}{c}12.64 \\
(15.08)\end{array}$ \\
\hline Preschooler & $\begin{array}{c}-16.26^{*} \\
(8.37)\end{array}$ & $\begin{array}{c}-2.98 \\
(10.01)\end{array}$ & $\begin{array}{l}18.44 * \\
(10.32)\end{array}$ & $\begin{array}{l}-14.74 \\
(10.68)\end{array}$ & $\begin{array}{l}-3.67 \\
(6.86)\end{array}$ & $\begin{array}{c}20.07 * * \\
(8.63)\end{array}$ & $\begin{array}{c}0.76 \\
(7.64)\end{array}$ & $\begin{array}{c}9.88 \\
(11.23)\end{array}$ \\
\hline Age, $20-30$ years & Ref. & Ref. & Ref. & Ref. & Ref. & Ref. & Ref. & Ref. \\
\hline 30-39 years & $\begin{array}{c}38.73 * * * \\
(8.39)\end{array}$ & $\begin{array}{c}28.17 * * * * \\
(9.62)\end{array}$ & $\begin{array}{c}6.58 \\
(9.20)\end{array}$ & $\begin{array}{c}21.77 * * \\
(10.26)\end{array}$ & $\begin{array}{c}26.64 * * * \\
(6.61)\end{array}$ & $\begin{array}{c}21.59 * * \\
(8.74)\end{array}$ & $\begin{array}{c}21.85 * * * \\
(6.58)\end{array}$ & $\begin{array}{c}11.67 \\
(10.01)\end{array}$ \\
\hline 40-49 years & $\begin{array}{c}70.42 * * * \\
(11.16)\end{array}$ & $\begin{array}{c}59.37 * * * \\
(10.44)\end{array}$ & $\begin{array}{l}21.29 * \\
(12.09)\end{array}$ & $\begin{array}{c}26.99 * * * \\
(9.28)\end{array}$ & $\begin{array}{c}36.88^{* * * *} \\
(7.05)\end{array}$ & $\begin{array}{c}51.40 * * * \\
(9.11)\end{array}$ & $\begin{array}{c}31.41 * * * \\
(7.18)\end{array}$ & $\begin{array}{c}27.57 * * \\
(10.91)\end{array}$ \\
\hline $50-60$ years & $\begin{array}{c}74.98 * * * \\
(11.89)\end{array}$ & $\begin{array}{c}90.72 * * * \\
(10.15)\end{array}$ & $\begin{array}{c}37.32 * * * \\
(13.88)\end{array}$ & $\begin{array}{c}51.03 * * * \\
(9.61)\end{array}$ & $\begin{array}{c}66.52 * * * \\
(7.98)\end{array}$ & $\begin{array}{c}63.10 * * * \\
(8.35)\end{array}$ & $\begin{array}{c}37.18 * * * \\
(7.10)\end{array}$ & $\begin{array}{c}45.15 * * * \\
(10.42)\end{array}$ \\
\hline Weekend & & & & & $\begin{array}{c}46.43 * * * \\
(4.44)\end{array}$ & $\begin{array}{c}56.38 * * * * \\
(5.08)\end{array}$ & $\begin{array}{c}75.13 * * * \\
(4.22)\end{array}$ & $\begin{array}{c}59.91 * * * \\
(5.94)\end{array}$ \\
\hline Constant & $\begin{array}{c}214.87 * * * \\
(14.16)\end{array}$ & $\begin{array}{c}200.53^{* * * *} \\
(16.19)\end{array}$ & $\begin{array}{c}105.87 * * * \\
(13.23)\end{array}$ & $\begin{array}{c}112.71 * * * \\
(14.22)\end{array}$ & $\begin{array}{c}175.43 * * * \\
(9.37)\end{array}$ & $\begin{array}{c}95.60 * * * \\
(14.88)\end{array}$ & $\begin{array}{c}71.24 * * * \\
(9.02)\end{array}$ & $\begin{array}{c}83.32 * * * \\
(15.84)\end{array}$ \\
\hline Observations & 1,337 & 797 & 1,015 & 624 & 3,925 & 2,549 & 3,354 & 1,901 \\
\hline R-squared & 0.45 & 0.41 & 0.21 & 0.20 & 0.10 & 0.11 & 0.11 & 0.10 \\
\hline
\end{tabular}


TABLE A4 Complete OLS regression output for daily housework, by gender, in the UK and USA.

\begin{tabular}{|c|c|c|c|c|c|c|c|c|}
\hline & \multicolumn{3}{|c|}{ UK } & \multicolumn{5}{|c|}{ USA } \\
\hline & Women & & Men & & Women & & Men & \\
\hline & 1983 & 2015 & 1983 & 2015 & 1985 & 2006 & 1985 & 2006 \\
\hline Employed & Ref. & Ref. & Ref. & Ref. & Ref. & Ref. & Ref. & Ref. \\
\hline Unemployed & $\begin{array}{c}143.93 * * * \\
(12.07)\end{array}$ & $\begin{array}{c}60.60 * * * \\
(9.02)\end{array}$ & $\begin{array}{c}87.55 * * * \\
(6.63)\end{array}$ & $\begin{array}{l}38.34 * * * \\
(7.66)\end{array}$ & $\begin{array}{c}112.19 * * * \\
(17.53)\end{array}$ & $\begin{array}{c}138.49 * * * \\
(22.44)\end{array}$ & $\begin{array}{c}81.03 * * * \\
(26.70)\end{array}$ & $\begin{array}{c}98.51 * * * \\
(20.02)\end{array}$ \\
\hline Studying & $\begin{array}{c}-5.57 \\
(19.33)\end{array}$ & $\begin{array}{l}-15.11 \\
(9.33)\end{array}$ & $\begin{array}{l}30.68 * * \\
(14.95)\end{array}$ & $\begin{array}{l}-10.12 \\
(9.16)\end{array}$ & $\begin{array}{c}13.13 \\
(18.49)\end{array}$ & $\begin{array}{l}53.17 * * * \\
(16.13)\end{array}$ & $\begin{array}{l}59.12^{*} \\
(31.82)\end{array}$ & $\begin{array}{l}-12.78 \\
(16.91)\end{array}$ \\
\hline Homemaker & $\begin{array}{c}132.37 * * * \\
(6.13)\end{array}$ & $\begin{array}{c}70.05 * * * \\
(5.46)\end{array}$ & $\begin{array}{l}297.04 * * * \\
(29.22)\end{array}$ & $\begin{array}{l}116.85 * * * \\
(16.25)\end{array}$ & $\begin{array}{c}108.53 * * * \\
(9.86)\end{array}$ & $\begin{array}{l}117.21 * * * \\
(10.11)\end{array}$ & & \\
\hline $\begin{array}{l}\text { Out of the labour } \\
\text { force }\end{array}$ & $\begin{array}{c}82.77 * * * \\
(12.69)\end{array}$ & $\begin{array}{l}57.70 * * * \\
(6.94)\end{array}$ & $\begin{array}{c}83.61 * * * \\
(12.35)\end{array}$ & $\begin{array}{c}43.89 * * * \\
(6.50)\end{array}$ & $\begin{array}{l}89.46 * * * \\
(25.51)\end{array}$ & $\begin{array}{l}75.26 * * * \\
(13.18)\end{array}$ & $\begin{array}{l}100.09 * * * \\
(23.70)\end{array}$ & $\begin{array}{c}39.78 * * * \\
(11.41)\end{array}$ \\
\hline Part time & $\begin{array}{c}77.01 * * * \\
(6.35)\end{array}$ & $\begin{array}{c}20.80 * * * \\
(3.79)\end{array}$ & $\begin{array}{l}21.28 * \\
(11.79)\end{array}$ & $\begin{array}{c}0.90 \\
(6.50)\end{array}$ & $\begin{array}{c}12.80 \\
(10.48)\end{array}$ & $\begin{array}{c}37.49 * * * \\
(6.99)\end{array}$ & $\begin{array}{c}-4.39 \\
(13.17)\end{array}$ & $\begin{array}{c}42.73 * * * \\
(15.59)\end{array}$ \\
\hline Education, low & Ref. & Ref. & Ref. & Ref. & Ref. & Ref. & Ref. & Ref. \\
\hline Secondary & -8.33 & -3.72 & $12.41 * *$ & 6.41 & 9.34 & -11.38 & -3.15 & $-16.70 *$ \\
\hline education & $(8.45)$ & $(6.27)$ & $(5.25)$ & $(6.17)$ & (11.02) & (11.96) & $(12.91)$ & $(9.36)$ \\
\hline Higher & $-18.35 * * *$ & -3.42 & $25.50 * * *$ & $11.75 * * *$ & -4.73 & -15.76 & 0.51 & 3.62 \\
\hline education & (5.06) & $(3.81)$ & $(5.82)$ & $(3.61)$ & (11.40) & $(10.81)$ & (13.18) & $(8.84)$ \\
\hline Married couple & Ref. & Ref. & Ref. & Ref. & Ref. & Ref. & Ref. & Ref. \\
\hline Unmarried & -16.95 & 2.26 & -22.54 & $14.57 * * *$ & $-59.29 * * *$ & -4.98 & $-32.46 * * *$ & 3.70 \\
\hline Couple & (13.34) & $(5.19)$ & $(14.56)$ & (4.97) & (11.58) & (16.39) & $(12.55)$ & (11.11) \\
\hline Single & $\begin{array}{l}-53.55 * * * \\
(5.63)\end{array}$ & $\begin{array}{c}-28.18 * * * \\
(4.21)\end{array}$ & $\begin{array}{c}-33.59 * * * \\
(6.86)\end{array}$ & $\begin{array}{c}-20.00 * * * \\
(4.54)\end{array}$ & $\begin{array}{c}-39.79 * * * \\
(8.63)\end{array}$ & $\begin{array}{c}-35.93 * * * \\
(5.86)\end{array}$ & $\begin{array}{c}0.71 \\
(10.58)\end{array}$ & $\begin{array}{c}0.23 \\
(6.27)\end{array}$ \\
\hline No children & $\begin{array}{l}-28.77 * * * \\
(6.47)\end{array}$ & $\begin{array}{c}-15.14 * * * \\
(5.23)\end{array}$ & $\begin{array}{l}-6.44 \\
(6.81)\end{array}$ & $\begin{array}{c}3.75 \\
(5.51)\end{array}$ & $\begin{array}{l}-10.40 \\
(10.01)\end{array}$ & $\begin{array}{l}-4.67 \\
(7.87)\end{array}$ & $\begin{array}{l}-20.71 * \\
(11.40)\end{array}$ & $\begin{array}{c}-15.21 * * \\
(7.17)\end{array}$ \\
\hline 1 child & Ref. & Ref. & Ref. & Ref. & Ref. & Ref. & Ref. & Ref. \\
\hline 2 children & $\begin{array}{c}6.83 \\
(6.62)\end{array}$ & $\begin{array}{c}14.03 * * \\
(5.65)\end{array}$ & $\begin{array}{c}-18.85 * * * \\
(7.12)\end{array}$ & $\begin{array}{c}4.65 \\
(5.96)\end{array}$ & $\begin{array}{c}13.27 \\
(12.33)\end{array}$ & $\begin{array}{l}11.61 * \\
(6.49)\end{array}$ & $\begin{array}{c}-10.04 \\
(11.51)\end{array}$ & $\begin{array}{l}-1.59 \\
(6.93)\end{array}$ \\
\hline 3 or more & $34.67 * * *$ & $33.05 * * *$ & $-17.37 * *$ & 8.13 & 10.65 & $24.22 * * *$ & $38.02 *$ & -7.84 \\
\hline children & $(7.94)$ & $(8.22)$ & $(8.42)$ & $(8.45)$ & (16.39) & $(8.35)$ & (19.98) & $(8.11)$ \\
\hline Preschooler & $\begin{array}{c}-20.25 * * * \\
(6.71)\end{array}$ & $\begin{array}{c}-11.28 * * \\
(5.27)\end{array}$ & $\begin{array}{l}-2.47 \\
(6.95)\end{array}$ & $\begin{array}{l}-1.11 \\
(5.45)\end{array}$ & $\begin{array}{c}16.45 \\
(12.32)\end{array}$ & $\begin{array}{c}-20.37 * * * \\
(6.78)\end{array}$ & $\begin{array}{c}-27.07 * * \\
(11.53)\end{array}$ & $\begin{array}{l}-9.06 \\
(7.00)\end{array}$ \\
\hline Age, $20-30$ years & Ref. & Ref. & Ref. & Ref. & Ref. & Ref. & Ref. & Ref. \\
\hline $30-39$ years & $\begin{array}{c}14.70 * * \\
(6.20)\end{array}$ & $\begin{array}{c}6.98 \\
(5.52)\end{array}$ & $\begin{array}{c}15.45^{* *} \\
(6.54)\end{array}$ & $\begin{array}{l}15.98 * * * \\
(5.43)\end{array}$ & $\begin{array}{l}37.03 * * * \\
(9.51)\end{array}$ & $\begin{array}{c}24.37 * * * \\
(8.34)\end{array}$ & $\begin{array}{l}12.66 \\
(9.83)\end{array}$ & $\begin{array}{c}16.74 * * \\
(7.07)\end{array}$ \\
\hline 40-49 years & $\begin{array}{c}45.93 * * * \\
(6.96)\end{array}$ & $\begin{array}{c}43.71 * * * \\
(5.31)\end{array}$ & $\begin{array}{c}21.57 * * * \\
(7.01)\end{array}$ & $\begin{array}{c}30.15 * * * \\
(5.41)\end{array}$ & $\begin{array}{c}50.46 * * * \\
(10.47)\end{array}$ & $\begin{array}{c}34.23 * * * \\
(8.18)\end{array}$ & $\begin{array}{c}11.47 \\
(10.85)\end{array}$ & $\begin{array}{c}25.50 * * * \\
(6.86)\end{array}$ \\
\hline 50-60 years & $\begin{array}{c}69.37 * * * \\
(7.63)\end{array}$ & $\begin{array}{c}58.32 * * * \\
(5.63)\end{array}$ & $\begin{array}{c}24.82 * * * \\
(7.19)\end{array}$ & $\begin{array}{c}53.79 * * * \\
(5.45)\end{array}$ & $\begin{array}{c}50.33 * * * \\
(10.89)\end{array}$ & $\begin{array}{c}46.29 * * * \\
(9.33)\end{array}$ & $\begin{array}{c}18.53 \\
(12.13)\end{array}$ & $\begin{array}{c}23.95 * * * \\
(7.10)\end{array}$ \\
\hline Weekend & $\begin{array}{c}12.63 * * * \\
(4.59)\end{array}$ & $\begin{array}{c}25.17 * * * \\
(3.45)\end{array}$ & $\begin{array}{l}50.71 * * * \\
(4.77)\end{array}$ & $\begin{array}{c}38.47 * * * \\
(3.36)\end{array}$ & $\begin{array}{c}38.45 * * * \\
(8.73)\end{array}$ & $\begin{array}{l}45.85 * * * \\
(5.52)\end{array}$ & $\begin{array}{l}35.93 * * * \\
(8.51)\end{array}$ & $\begin{array}{c}69.69 * * * \\
(4.88)\end{array}$ \\
\hline Constant & $\begin{array}{c}170.25 * * * \\
(8.16)\end{array}$ & $\begin{array}{c}137.65 * * * \\
(7.63)\end{array}$ & $\begin{array}{c}60.95 * * * \\
(8.06)\end{array}$ & $\begin{array}{c}54.48 * * * \\
(7.34)\end{array}$ & $\begin{array}{c}139.90 * * * \\
(14.44)\end{array}$ & $\begin{array}{c}114.13 * * * \\
(13.54)\end{array}$ & $\begin{array}{c}93.55 * * * \\
(16.54)\end{array}$ & $\begin{array}{c}59.50 * * * \\
(10.86)\end{array}$ \\
\hline Observations & 3,746 & 5,218 & 2,431 & 4,390 & 1,402 & 4,564 & 1,173 & 3,476 \\
\hline R-squared & 0.30 & 0.13 & 0.16 & 0.10 & 0.20 & 0.14 & 0.08 & 0.10 \\
\hline
\end{tabular}
Note: Standard errors in parentheses. $* * * \mathrm{p}<0.01, * * \mathrm{p}<0.05, * \mathrm{p}<0.1$ 
TABLE A5 Complete OLS regression output for daily childcare, by gender, in France and Italy.

\begin{tabular}{|c|c|c|c|c|c|c|c|c|}
\hline & \multicolumn{3}{|c|}{ France } & \multicolumn{5}{|c|}{ Italy } \\
\hline & $\begin{array}{c}\text { Women } \\
1985\end{array}$ & 2010 & $\begin{array}{l}\text { Men } \\
1985\end{array}$ & 2010 & $\begin{array}{c}\text { Women } \\
1988\end{array}$ & 2008 & $\begin{array}{l}\text { Men } \\
1988\end{array}$ & 2008 \\
\hline Employed & Ref. & Ref. & Ref. & Ref. & Ref. & Ref. & Ref. & Ref. \\
\hline Unemployed & $\begin{array}{c}28.07 * * * \\
(6.85)\end{array}$ & $\begin{array}{c}35.82 * * * \\
(11.16)\end{array}$ & $\begin{array}{l}18.74 * * * \\
(5.59)\end{array}$ & $\begin{array}{c}23.99 * * * \\
(8.02)\end{array}$ & $\begin{array}{c}20.72 * * * \\
(7.37)\end{array}$ & $\begin{array}{c}20.09 * * * \\
(7.73)\end{array}$ & $\begin{array}{c}13.03 * * \\
(5.95)\end{array}$ & $\begin{array}{c}37.32 * * * \\
(9.71)\end{array}$ \\
\hline Studying & $\begin{array}{l}-21.40 \\
(29.75)\end{array}$ & $\begin{array}{c}6.18 \\
(40.69)\end{array}$ & $\begin{array}{c}-24.69 * * * \\
(7.69)\end{array}$ & $\begin{array}{c}-55.02 * * * \\
(12.16)\end{array}$ & $\begin{array}{c}15.10 \\
(61.05)\end{array}$ & $\begin{array}{l}50.39 * \\
(28.86)\end{array}$ & & \\
\hline Homemaker & $\begin{array}{c}38.96 * * * \\
(3.41)\end{array}$ & $\begin{array}{c}67.55 * * * \\
(9.03)\end{array}$ & $\begin{array}{c}38.92 \\
(31.39)\end{array}$ & $\begin{array}{c}77.56 * * * \\
(28.45)\end{array}$ & $\begin{array}{c}19.02 * * * \\
(2.50)\end{array}$ & $\begin{array}{c}33.57 * * * \\
(4.27)\end{array}$ & & \\
\hline $\begin{array}{l}\text { Out of the labour } \\
\text { force }\end{array}$ & $\begin{array}{c}60.00 * * * \\
(20.34)\end{array}$ & $\begin{array}{c}51.99 * * * \\
(16.89)\end{array}$ & $\begin{array}{c}2.49 \\
(4.07)\end{array}$ & $\begin{array}{c}64.39 \\
(52.29)\end{array}$ & $\begin{array}{c}20.55^{* * * *} \\
(6.23)\end{array}$ & $\begin{array}{c}22.09 \\
(18.42)\end{array}$ & $\begin{array}{c}16.45^{* * * *} \\
(5.58)\end{array}$ & $\begin{array}{c}30.26 * * * \\
(10.57)\end{array}$ \\
\hline Part time & $\begin{array}{l}-6.44 * \\
(3.75)\end{array}$ & $\begin{array}{c}20.29 * * * \\
(5.48)\end{array}$ & $\begin{array}{c}14.41 \\
(11.06)\end{array}$ & $\begin{array}{c}14.71 \\
(9.08)\end{array}$ & & & & \\
\hline Education, low & Ref. & Ref. & Ref. & Ref. & Ref. & Ref. & Ref. & Ref. \\
\hline $\begin{array}{l}\text { Secondary } \\
\text { education }\end{array}$ & $\begin{array}{c}13.30 * * * \\
(2.99)\end{array}$ & $\begin{array}{c}16.25 * * \\
(7.35)\end{array}$ & $\begin{array}{l}2.45^{*} \\
(1.48)\end{array}$ & $\begin{array}{c}1.86 \\
(4.44)\end{array}$ & $\begin{array}{l}19.12 * * * \\
(2.83)\end{array}$ & $\begin{array}{c}17.49 * * * \\
(3.91)\end{array}$ & $\begin{array}{c}9.87 * * * \\
(1.78)\end{array}$ & $\begin{array}{c}11.66 * * * \\
(2.72)\end{array}$ \\
\hline $\begin{array}{l}\text { Higher } \\
\text { education }\end{array}$ & $\begin{array}{c}36.62 * * * \\
(4.28)\end{array}$ & $\begin{array}{c}23.61 * * * \\
(7.62)\end{array}$ & $\begin{array}{c}14.05^{* * * *} \\
(2.41)\end{array}$ & $\begin{array}{c}17.55^{* * * *} \\
(5.01)\end{array}$ & $\begin{array}{c}30.31 * * * \\
(5.83)\end{array}$ & $\begin{array}{c}40.62 * * * \\
(6.13)\end{array}$ & $\begin{array}{c}15.88 * * * \\
(3.29)\end{array}$ & $\begin{array}{c}10.61 * * * \\
(3.37)\end{array}$ \\
\hline Married couple & Ref. & Ref. & Ref. & Ref. & Ref. & Ref. & Ref. & Ref. \\
\hline Unmarried & 0.18 & $11.51 *$ & -1.50 & $11.47 * *$ & 18.59 & $23.40 * *$ & 10.57 & 6.86 \\
\hline Couple & $(6.49)$ & $(6.52)$ & $(3.26)$ & $(5.09)$ & $(12.60)$ & $(9.64)$ & $(6.55)$ & $(6.17)$ \\
\hline Single & $\begin{array}{c}7.59 \\
(5.07)\end{array}$ & $\begin{array}{l}-11.13 \\
(6.81)\end{array}$ & $\begin{array}{l}5.85 \\
(6.62)\end{array}$ & $\begin{array}{c}13.79 \\
(11.87)\end{array}$ & $\begin{array}{l}8.67 * \\
(5.05)\end{array}$ & $\begin{array}{c}13.63 * * \\
(5.39)\end{array}$ & $\begin{array}{c}-8.92 * * * \\
(3.06)\end{array}$ & $\begin{array}{l}31.42 * * \\
(13.90)\end{array}$ \\
\hline 1 child (ref.) & Ref. & Ref. & Ref. & Ref. & Ref. & Ref. & Ref. & Ref. \\
\hline 2 children & $\begin{array}{c}14.05 * * * \\
(2.85)\end{array}$ & $\begin{array}{c}4.96 \\
(5.32)\end{array}$ & $\begin{array}{c}4.22 * * \\
(1.76)\end{array}$ & $\begin{array}{c}3.92 \\
(4.51)\end{array}$ & $\begin{array}{c}5.06 * * \\
(2.56)\end{array}$ & $\begin{array}{c}29.51 * * * \\
(3.95)\end{array}$ & $\begin{array}{l}-2.13 \\
(1.64)\end{array}$ & $\begin{array}{c}7.19 * * * \\
(2.69)\end{array}$ \\
\hline $\begin{array}{l}3 \text { or more } \\
\text { children }\end{array}$ & $\begin{array}{c}18.35 * * * \\
(4.02)\end{array}$ & $\begin{array}{c}14.26^{* *} \\
(7.11)\end{array}$ & $\begin{array}{l}-2.13 \\
(1.91)\end{array}$ & $\begin{array}{c}5.96 \\
(6.00)\end{array}$ & $\begin{array}{l}8.82 * * \\
(4.13)\end{array}$ & $\begin{array}{c}18.34 * * \\
(8.19)\end{array}$ & $\begin{array}{l}-3.98 \\
(2.84)\end{array}$ & $\begin{array}{l}8.38 * \\
(4.88)\end{array}$ \\
\hline Preschooler & $\begin{array}{c}72.90 * * * \\
(3.66)\end{array}$ & $\begin{array}{c}62.15 * * * \\
(6.49)\end{array}$ & $\begin{array}{c}18.33 * * * \\
(1.68)\end{array}$ & $\begin{array}{c}30.31 * * * \\
(3.90)\end{array}$ & $\begin{array}{c}61.77 * * * \\
(3.14)\end{array}$ & $\begin{array}{c}94.80 * * * \\
(4.92)\end{array}$ & $\begin{array}{c}20.01 * * * \\
(1.85)\end{array}$ & $\begin{array}{c}38.76 * * * \\
(3.21)\end{array}$ \\
\hline Age, $20-30$ years & Ref. & Ref. & Ref. & Ref. & Ref. & Ref. & Ref. & Ref. \\
\hline $30-39$ years & $\begin{array}{c}-31.35 * * * \\
(4.53)\end{array}$ & $\begin{array}{l}-17.74 * \\
(10.28)\end{array}$ & $\begin{array}{l}-2.82 \\
(3.02)\end{array}$ & $\begin{array}{l}-10.51 \\
(12.16)\end{array}$ & $\begin{array}{c}-18.67 * * * \\
(4.35)\end{array}$ & $\begin{array}{l}-5.62 \\
(9.37)\end{array}$ & $\begin{array}{c}1.57 \\
(3.73)\end{array}$ & $\begin{array}{c}10.45 \\
(11.21)\end{array}$ \\
\hline 40-49 years & $\begin{array}{c}-50.47 * * * \\
(5.60)\end{array}$ & $\begin{array}{c}-39.98 * * * \\
(11.60)\end{array}$ & $\begin{array}{c}-8.98 * * * \\
(3.28)\end{array}$ & $\begin{array}{l}-21.73^{*} \\
(12.29)\end{array}$ & $\begin{array}{c}-34.26 * * * \\
(4.44)\end{array}$ & $\begin{array}{c}-31.09 * * * \\
(9.66)\end{array}$ & $\begin{array}{l}-6.27 \\
(3.88)\end{array}$ & $\begin{array}{c}4.57 \\
(11.28)\end{array}$ \\
\hline $50-60$ years & $\begin{array}{c}-54.17 * * * \\
(6.47)\end{array}$ & $\begin{array}{c}-45.65 * * * \\
(12.15)\end{array}$ & $\begin{array}{c}-9.84 * * \\
(4.04)\end{array}$ & $\begin{array}{c}-34.80 * * \\
(16.05)\end{array}$ & $\begin{array}{c}-45.34 * * * \\
(4.45)\end{array}$ & $\begin{array}{c}-46.86 * * * \\
(10.46)\end{array}$ & $\begin{array}{c}-11.21 * * * \\
(3.83)\end{array}$ & $\begin{array}{c}-0.42 \\
(11.63)\end{array}$ \\
\hline Weekend & $\begin{array}{c}-8.17 * * * \\
(3.04)\end{array}$ & $\begin{array}{c}-28.98 * * * \\
(5.27)\end{array}$ & $\begin{array}{c}7.89 * * * \\
(1.79)\end{array}$ & $\begin{array}{c}4.70 \\
(4.68)\end{array}$ & $\begin{array}{c}-9.00 * * * \\
(1.80)\end{array}$ & $\begin{array}{c}-29.47 * * * \\
(2.93)\end{array}$ & $\begin{array}{c}3.65 * * * \\
(1.21)\end{array}$ & $\begin{array}{c}10.66 * * * \\
(2.18)\end{array}$ \\
\hline Constant & $\begin{array}{c}42.92 * * * \\
(5.23)\end{array}$ & $\begin{array}{c}52.45^{* * *} * \\
(13.71)\end{array}$ & $\begin{array}{c}9.76 * * * \\
(3.14)\end{array}$ & $\begin{array}{c}24.68 * * \\
(12.34)\end{array}$ & $\begin{array}{c}32.94 * * * \\
(4.66)\end{array}$ & $\begin{array}{c}53.76^{* * * *} \\
(9.99)\end{array}$ & $\begin{array}{c}8.55^{* *} \\
(3.65)\end{array}$ & $\begin{array}{c}8.01 \\
(11.15)\end{array}$ \\
\hline Observations & 3,529 & 2,817 & 3,038 & 2,359 & 5,528 & 4,284 & 5,239 & 3,806 \\
\hline R-squared & 0.37 & 0.29 & 0.12 & 0.15 & 0.32 & 0.34 & 0.11 & 0.13 \\
\hline
\end{tabular}


TABLE A6 Complete OLS regression output for daily childcare, by gender, in the Netherlands and Sweden.

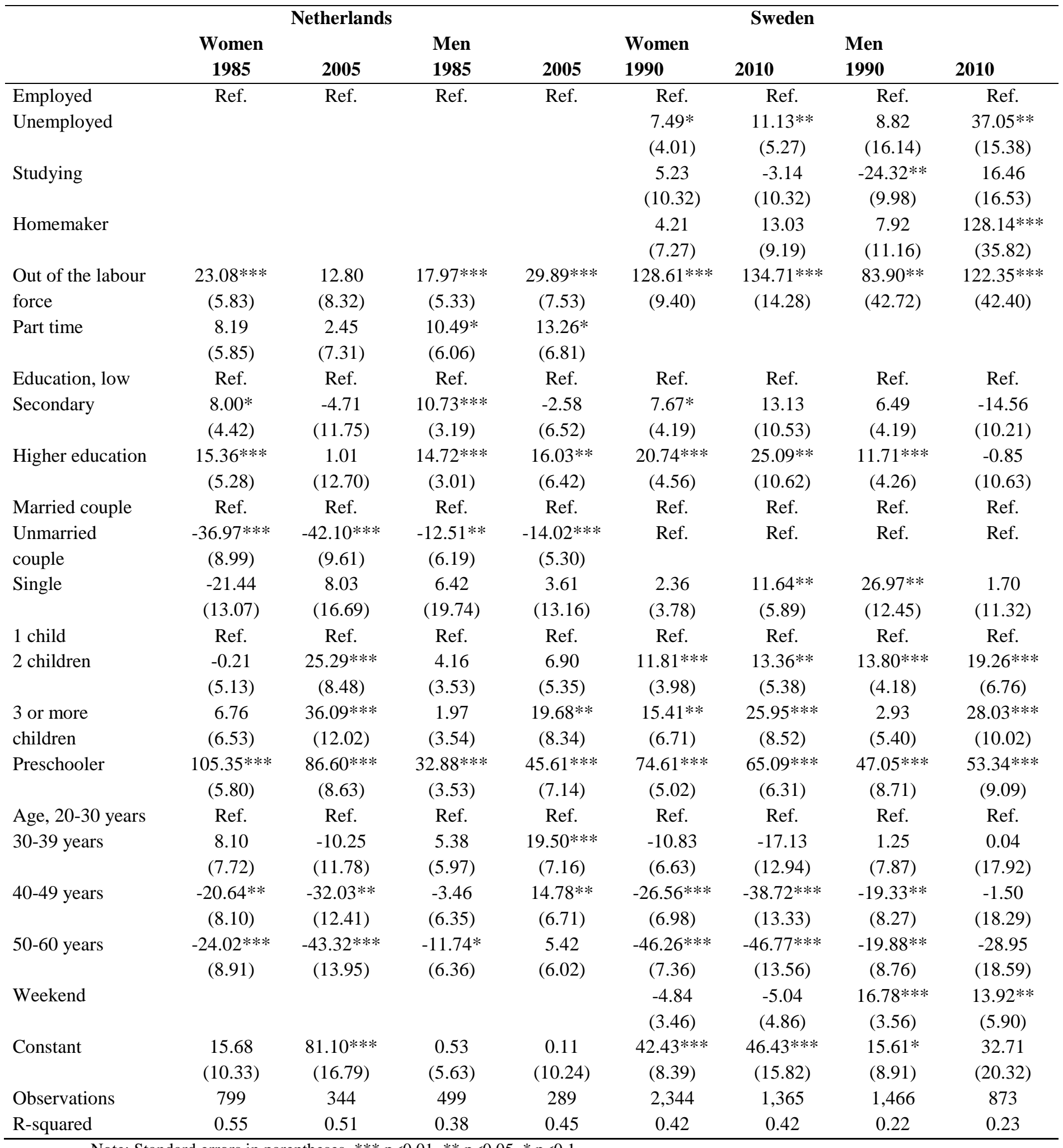


TABLE A7 Complete OLS regressions for daily childcare, by gender, in the UK and USA.

\begin{tabular}{|c|c|c|c|c|c|c|c|c|}
\hline & \multicolumn{3}{|c|}{$\mathbf{U K}$} & \multicolumn{5}{|c|}{ USA } \\
\hline & Women & & Men & & Women & & Men & \\
\hline & 1983 & 2015 & 1983 & 2015 & 1985 & 2006 & 1985 & 2006 \\
\hline Employed & Ref. & Ref. & Ref. & Ref. & Ref. & Ref. & Ref. & Ref. \\
\hline \multirow{2}{*}{ Unemployed } & $37.58 * * *$ & 1.00 & $12.82 * * *$ & $30.65 * * *$ & $51.58^{*}$ & $28.41 * *$ & -2.39 & $53.73 * * *$ \\
\hline & $(11.13)$ & (11.87) & $(4.56)$ & $(9.40)$ & $(30.05)$ & $(12.68)$ & $(10.49)$ & $(17.92)$ \\
\hline \multirow[t]{2}{*}{ Studying } & 11.22 & $-28.20 *$ & -16.72 & -15.89 & $54.23 * *$ & 21.17 & -4.58 & 41.59 \\
\hline & $(18.20)$ & $(15.03)$ & $(15.30)$ & $(18.24)$ & $(25.32)$ & $(17.40)$ & $(5.17)$ & $(60.66)$ \\
\hline \multirow[t]{2}{*}{ Homemaker } & $41.48 * * *$ & $34.19 * * *$ & $59.43 * * *$ & $80.98 * * *$ & $31.63 * * *$ & $76.29 * * *$ & & \\
\hline & $(5.10)$ & $(5.34)$ & $(15.50)$ & $(15.62)$ & $(8.06)$ & $(8.01)$ & & \\
\hline Out of the labour & 7.50 & -5.20 & 0.76 & 13.13 & 2.40 & $51.40 * * *$ & 29.44 & $44.03 * * *$ \\
\hline force & (16.19) & (11.43) & $(9.73)$ & $(10.90)$ & $(14.98)$ & (11.91) & $(22.49)$ & (13.00) \\
\hline \multirow[t]{2}{*}{ Part time } & $13.22 * *$ & 4.19 & 4.40 & 8.21 & 12.93 & $20.99 * * *$ & -5.69 & 6.05 \\
\hline & $(5.32)$ & $(4.32)$ & $(7.80)$ & $(7.51)$ & $(9.00)$ & $(5.73)$ & $(5.23)$ & $(13.51)$ \\
\hline Education, low & Ref. & Ref. & Ref. & Ref. & Ref. & Ref. & Ref. & Ref. \\
\hline Secondary & $15.70^{* *}$ & 7.05 & 0.23 & $16.45^{* *}$ & 11.29 & $25.67 * * *$ & 1.95 & $17.36^{* * *}$ \\
\hline education & (7.89) & (7.98) & (3.68) & $(7.23)$ & (9.24) & $(9.60)$ & $(8.63)$ & (6.61) \\
\hline Higher & $28.00 * * *$ & $22.14 * * *$ & $15.37 * * *$ & $19.86 * * *$ & $15.54 *$ & $51.34 * * *$ & 5.07 & $38.81 * * *$ \\
\hline education & (4.18) & $(4.75)$ & (4.02) & (4.04) & $(9.15)$ & $(8.51)$ & (9.10) & $(5.78)$ \\
\hline Married couple & Ref. & Ref. & Ref. & Ref. & Ref. & Ref. & Ref. & Ref. \\
\hline Unmarried & -2.28 & $-16.91 * * *$ & -13.46 & -0.27 & $-40.05 * * *$ & -14.98 & -1.90 & -5.10 \\
\hline Couple & $(14.25)$ & (6.13) & $(12.23)$ & $(5.11)$ & (13.04) & (14.92) & $(5.80)$ & (11.33) \\
\hline \multirow[t]{2}{*}{ Single } & $-23.75 * * *$ & -8.58 & -3.13 & $-14.82 * *$ & $-14.67 *$ & -2.38 & 10.87 & $17.08 *$ \\
\hline & (5.10) & $(5.40)$ & (7.79) & (6.88) & $(8.56)$ & $(6.02)$ & $(9.05)$ & (10.07) \\
\hline 1 child & Ref. & Ref. & Ref. & Ref. & Ref. & Ref. & Ref. & Ref. \\
\hline \multirow{2}{*}{2 children } & -0.91 & $17.15^{* * *}$ & 1.17 & $14.42 * * *$ & 4.31 & $29.93 * * *$ & $9.53 *$ & $9.00 *$ \\
\hline & $(4.36)$ & $(4.67)$ & $(3.80)$ & $(4.25)$ & (7.24) & $(5.21)$ & $(5.01)$ & $(4.65)$ \\
\hline 3 or more & 3.25 & $16.08 * *$ & $8.81 * *$ & 5.25 & 10.35 & $36.18 * * *$ & -1.86 & $15.97 * * *$ \\
\hline children & $(5.12)$ & $(6.82)$ & $(4.45)$ & $(6.01)$ & $(10.32)$ & (7.34) & $(6.34)$ & $(6.03)$ \\
\hline \multirow[t]{2}{*}{ Preschooler } & $109.56^{* * *}$ & $77.10 * * *$ & $31.17 * * *$ & $52.21 * * *$ & $79.91 * * *$ & $73.00 * * *$ & $29.85 * * *$ & $39.58 * * *$ \\
\hline & (4.68) & $(5.01)$ & (4.27) & (4.37) & $(9.03)$ & $(6.45)$ & $(7.94)$ & $(5.31)$ \\
\hline Age, $20-30$ years & Ref. & Ref. & Ref. & Ref. & Ref. & Ref. & Ref. & Ref. \\
\hline \multirow[t]{2}{*}{$30-39$ years } & $18.81 * * *$ & -3.39 & $15.44 * * *$ & $15.60 * *$ & -9.77 & -5.08 & 10.59 & 9.59 \\
\hline & (4.94) & $(6.43)$ & $(4.81)$ & $(6.78)$ & $(10.40)$ & $(8.41)$ & $(7.23)$ & (7.99) \\
\hline \multirow[t]{2}{*}{$40-49$ years } & $-13.29 * *$ & $-47.01 * * *$ & $10.53^{*}$ & 1.81 & $-34.94 * * *$ & $-18.13 * *$ & 9.81 & 8.62 \\
\hline & (6.19) & (7.04) & $(5.83)$ & $(6.94)$ & (10.16) & $(8.86)$ & $(8.49)$ & $(8.56)$ \\
\hline \multirow[t]{2}{*}{$50-60$ years } & $-21.33 * *$ & $-56.86 * * *$ & 0.85 & -6.62 & $-25.47 *$ & $-42.47 * * *$ & 16.80 & -5.04 \\
\hline & $(9.47)$ & (10.01) & $(7.05)$ & $(8.32)$ & $(14.62)$ & $(10.15)$ & $(13.16)$ & $(9.52)$ \\
\hline \multirow[t]{2}{*}{ Weekend } & $-25.78 * * *$ & $-27.30 * * *$ & 3.15 & $17.75 * * *$ & $-24.53 * * *$ & $-42.25^{* * *}$ & 0.14 & $11.22 * * *$ \\
\hline & (3.72) & (4.17) & $(3.28)$ & (3.78) & $(6.42)$ & $(4.43)$ & $(5.08)$ & $(4.17)$ \\
\hline \multirow[t]{2}{*}{ Constant } & $24.10 * * *$ & $83.28 * * *$ & 1.21 & -3.15 & $45.10 * * *$ & $24.50 * *$ & -2.82 & -9.26 \\
\hline & (7.13) & $(8.76)$ & $(5.95)$ & $(8.02)$ & (11.97) & $(11.36)$ & $(10.44)$ & $(10.00)$ \\
\hline Observations & 2,211 & 2,349 & 1,359 & 1,686 & 650 & 2,986 & 530 & 2,066 \\
\hline R-squared & 0.43 & 0.28 & 0.13 & 0.18 & 0.33 & 0.25 & 0.10 & 0.10 \\
\hline
\end{tabular}

Note: Standard errors in parentheses. $* * * \mathrm{p}<0.01, * * \mathrm{p}<0.05, * \mathrm{p}<0.1$ 


\section{FIGURE 1 Convergence in housework and childcare}

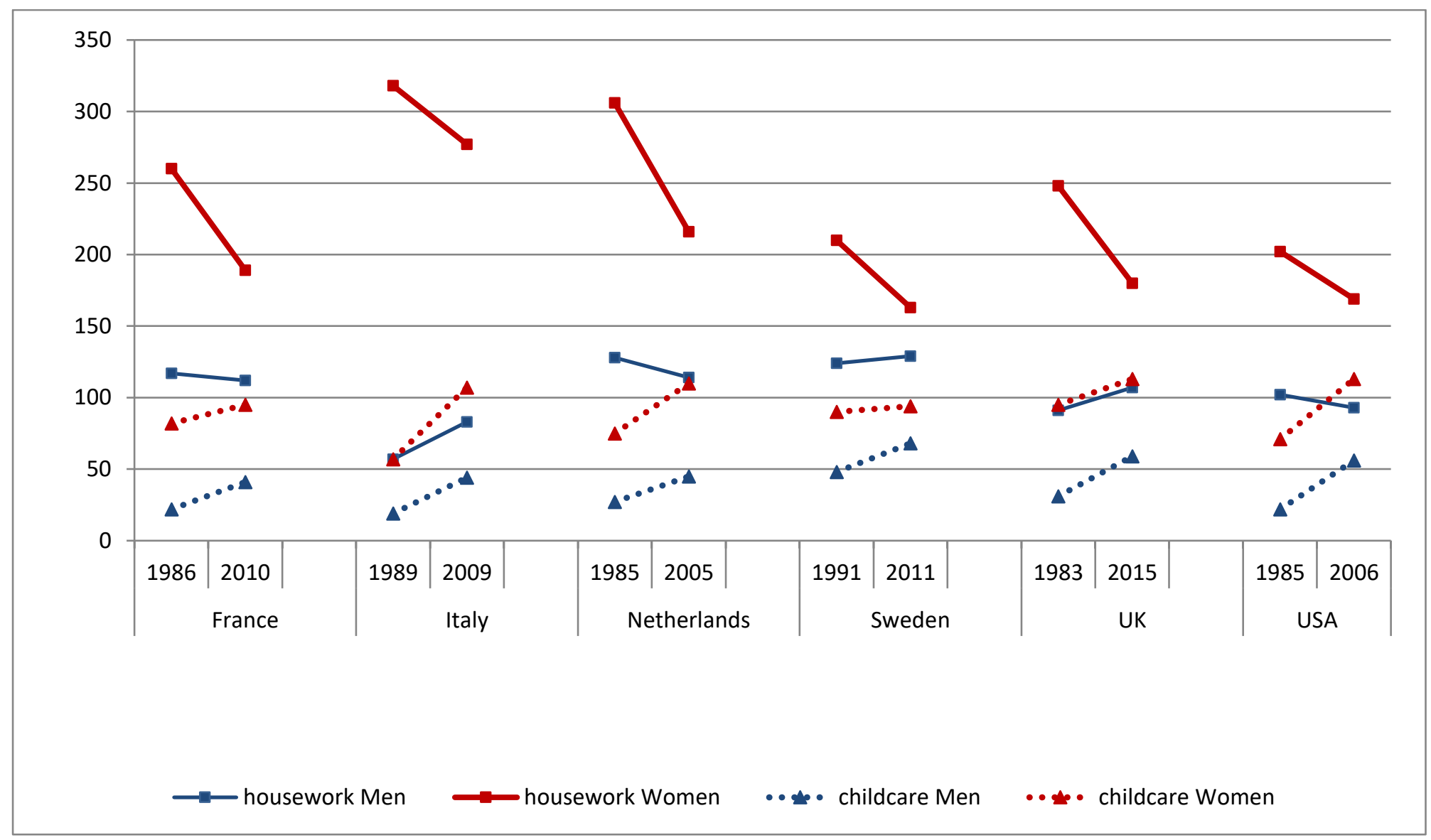


FIGURE 2 Main results of the decomposition of change in housework and childcare

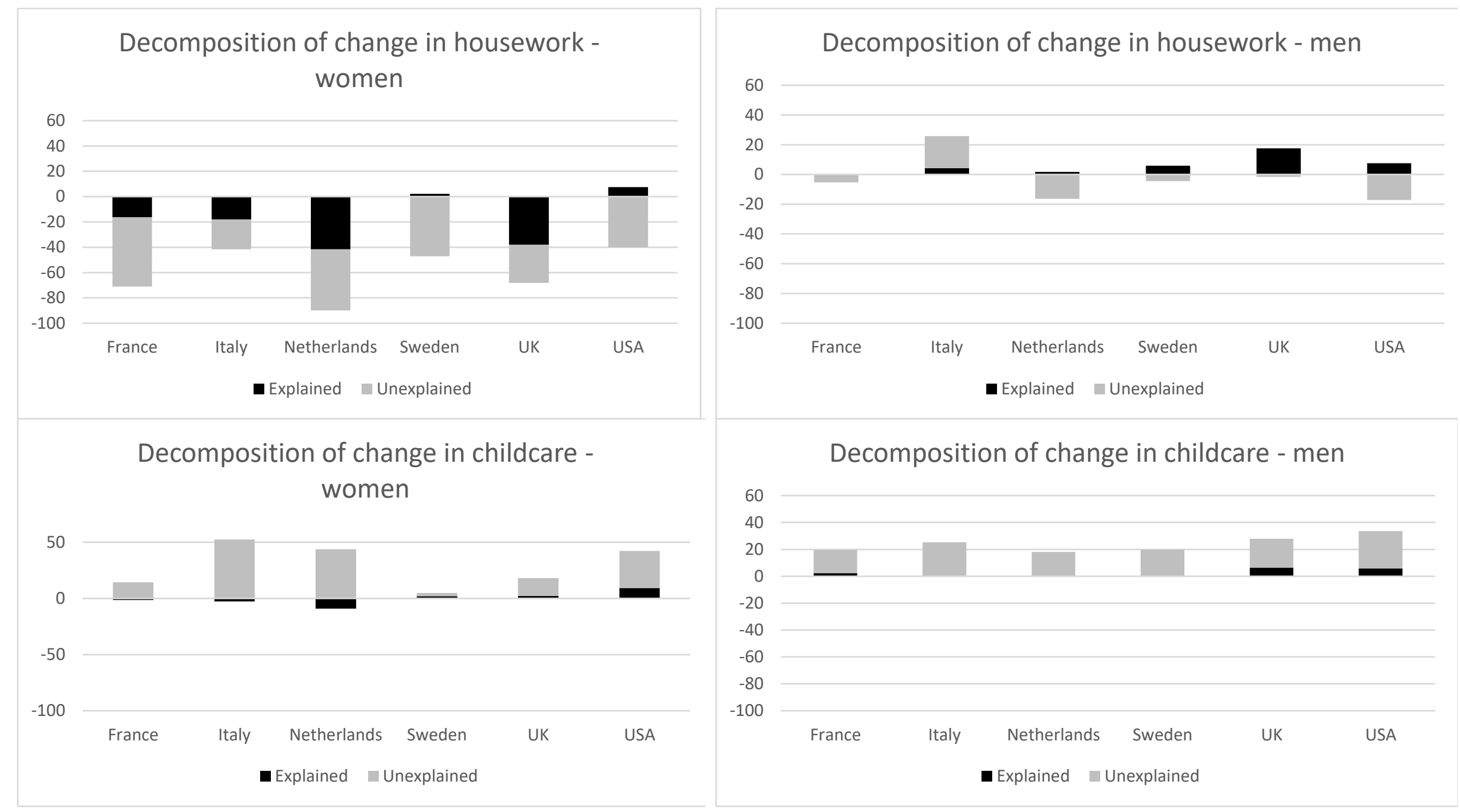


${ }^{1} \mathrm{We}$ acknowledge the literature emphasizing that the selfsame technological advances do not necessarily lead to less time spent on domestic work; see Vanek (1974) and Gershuny (2004). ${ }^{2}$ Esping-Andersen's typology has been scrutinized by feminist scholars who suggest the categorization is more applicable to class than gender because it does not account for unpaid work activities and care work (e.g. Orloff 1996; Sainsbury 1996). The broad categorization also misses economic, family, welfare or gender policy nuances (Gershuny \& Sullivan 2003). We acknowledge these objections, but use the typology as a framework for exploring whether there is gender convergence in unpaid work along welfare state regime type lines.

${ }^{3}$ In France, the benefit associated with parental leave is very low, i.e. half of the minimum wage, and few men take up this opportunity.

${ }^{4}$ Data for the United States are available only for 1990.

${ }^{5}$ There are more recent American Time Use Surveys. We have chosen 2006 because it preceded the Great Recession that hit the United States in 2008 and severely impacted men's and women's work patterns, income, but also family life and time use.

${ }^{6}$ Descriptive statistics and model estimates presented are weighted to account for population distribution and over-sampling.

${ }^{7}$ These declines apply to both average time in general and the average time for participants because the participation rates among women have not really changed. This illustrates the fact that change in housework among women primarily takes place on the intensive margin.

${ }^{8}$ Worth noting, the figures presented in Table 6 relate to time spent on activities explicitly devoted to children and do not include time with children just being present. This childcare measure is straightforward and uncontroversial, but an under-estimation of gender differences in total time with children. 